\title{
THE FORUM JOURNAL OF HISTORY
}

Volume 11 Spring 2019

Phi Alpha Theta, Alpha Nu Gamma Chapter

California Polytechnic State University, San Luis Obispo 


\section{CALIFORNIA POLYTECHNIC STATE UNIVERSITY SAN LUIS OBISPO}

Published in the United States of America

by the Cal Poly History Department

1 Grand Avenue, Building 47, Office 27c

San Luis Obispo, CA 93407

Copyright (C) 2019 California Polytechnic State University San Luis Obispo

Cover art copyright (C) 2019 Kieran Brady

Neither the editors nor Cal Poly assume responsibility for statements of fact or opinion made by the contributors.

All Rights Reserved. Except in those cases which comply with the fair use guidelines of U.S. copyright law (U.S.C Title 17), no part of this publication may be reproduced, stored in a retrieval system, or transmitted in any form by any means, electronic, mechanical, or otherwise, without the prior permission from the publisher.

All articles appearing in this journal are simultaneously published electronically via the DigitalCommons@CalPoly and are therefore subject to the terms specified in the Non-Exclusive License Agreement for Use of Materials in the DigitalCommons@CalPoly. http://digital commons.calpoly.edu/forum/

ISSN 2153-7178

ISSN 2153-7119 


\section{TABLE OF CONTENTS}

\section{FRONT MATTER}

iii Journal Staff

v Editor's Note

\section{ARTICLES}

1 Truth, Lies, and Misdeeds at Mauritius: The Story of the Schooner Industry Paul J Michaels

21 Slaving Vessel Soleil (Tigre): 1825 Voyage from Port of Mahe, Seychelles

Islands to St. Augustin's Bay, Madagascar

Jill O'Connor

45 The Uniao: Inhumanity and Complexities of the Transatlantic Slave Trade, $1820 \mathrm{~s}$

Amanda Casillas

67 Foundational Dissent: The 1965 Quota Controversy

Emily Taketa

75 A War of Rebellion: Radical Politics in the Spanish Civil War Hunter White

93 A 21st Century Empire: The British Museum and its Imperial Legacies Paige Rooney

107 North Vietnamese Women in War: Redefining Victory and Gender Roles Kali deVarrenes

\section{BACK MATTER}

\section{$121 \quad$ Editors}

Kelly Barr, Jacob Lafarga, John Imobersteg 


\section{JOURNAL STAFF}

EXECUTIVE EDITOR

Kelly Barr

ASSISTANT EDITORS

Jacob Lafarga

John Imobersteg

Elias Atienza

GRAPHIC DESIGNER

Kieran Brady

\section{FACULTY ADVISOR}

Dr. Lewis Call 


\section{EDITOR'S NOTE}

Welcome to the eleventh edition of The Forum, Cal Poly's own student written and student published historical journal. The school's motto is "Learn by Doing," and The Forum perfectly exemplifies that approach. Each year, the journal is the product of Cal Poly students doing history—researching, writing, and publishing scholarly work. This edition includes essays from all class levels. Ms. Taketa wrote her essay in History 100, the first course every history major takes as a freshman. Mr. Michaels is a current graduate student. Thus, this edition showcases the progress that every history major achieves during their time at Cal Poly.

I thank the wonderful team of editors that worked tirelessly to refine each of these submissions. Publishing the journal would be an insurmountable task without their help. I would also like to thank Dr. Lewis Call, our faculty advisor, for guiding us through this process as well as the faculty members that recognized and recommended each of these superb submissions. It goes without saying that the journal would not be possible without students courageously submitting their work to scrutiny. While many of the essays we received were of publishable quality, unfortunately we could only accept so many. I hope the edits that each author received were helpful to their progress as a writer, and I encourage every student to submit in the future. It's a pleasure every year to see what history students are working on and to admire the quality of work that the department produces.

I hope you enjoy this edition of The Forum, and I hope it encourages us all to keep on writing!

Kelly Barr 
ARTICLES 


\section{AUTHOR BIOGRAPHY PAUL J MICHAELS}

Paul J. Michaels is a second year MA History student from Lompoc, California. His research interests include the transoceanic slave trade, cultural and migration studies of nineteenth century Eastern Europe, and legal history. Paul's MA thesis investigated Boston Brahmin complicity in the transatlantic slave trade to Havana in the 1830s and 1840s, while his BA senior project examined the gendered national identities of Polish immigrants to the United States at the turn of the twentieth century. Paul will begin the teaching credential program at Cal Poly this summer. 


\section{Truth, Lies, and Misdeeds at Mauritius: The Story of the Schooner Industry}

\section{PAUL J MICHAELS}

When one thinks of the African slave trade, the image conjured is one of the Middle Passage across the Atlantic Ocean: millions of captured men, women, and children forcibly transported thousands of miles to the Americas doomed to lives of hard labor, some arbitrarily thrown overboard when food was in short supply and beaten within an inch of their lives on the whims of their Western European captors. While it is correct that this was often the case, the African slave trade was not always carried out by a renegade brig, overloaded with hundreds of captives, streaking across the Atlantic Ocean to avoid detection before making landfall. Countless African slaves were transported over the Indian Ocean-not just to Arab ports where the trade was allowed to continue under treaty with the British Crown, but also to British territories themselves.

Access to the report books of His Majesty's Treasury, chroni- 
cling the interception and transaction of illicit trade of human labor and contraband in the nineteenth century, has helped to illustrate the bygone era of Indian Ocean slave trade in the years following its abolition by the British Crown and Parliament. British physical presence in the Atlantic was decreasing, notably manifest by the independence of United States - the opposite was true in the Indian Ocean. The British Empire was actively "expanding and consolidating its positions in the Indian Ocean... [capturing] strategic points from the Cape of Good Hope...to Malacca," its influence growing exponentially which in turn brought widespread "pressure to enforce British anti-slave trade laws." 1

Application of these laws were not fully enforced until 1813, three years after the British took control of Île de France-today's Mauritius. Nonetheless, the slave trade continued to the island from East African ports due to "the French neither seriously enforcing their own anti-slave trade legislation nor allowing the British to search vessels flying the French flag." ${ }^{2}$ This is where the Treasury reports begin to tell the untold stories of ships captured en route to the Mascarene Islands, some overloaded with African captives being transported to the sugar plantations there. Despite an attempt to prevent the enforcement of the Abolition Act to Mauritius due to its being a "new" British colony put under British rule after 1807, Governor Robert Townsend Farquhar was overruled by his superiors and put the law into effect.

1 Robert Harms, Indian Ocean Slavery in the Age of Abolition, ed. Robert Harms, Bernard K. Freamon, and David W. Blight (New Haven, CT: Yale University Press, 2013), 8 .

2 Ibid., 9. 
The capturing of offending vessels began in earnest shortly thereafter, and by February 1817 a total of 1,312 slaves had been freed from slave ships. ${ }^{3}$ Despite this, Farquhar estimated a total of 30,000 slaves had successfully been imported to Mauritius between 1811 and 1821, with only 19 percent of slaves intercepted before making landfall. ${ }^{4}$ Some of those 19 percent freed before reaching Mauritius were the 127 people aboard the schooner Industry. This paper will, with the aid of the report books of His Majesty's Treasury and various first-hand accounts, argue for the exceptional nature of the Industry through compelling evidence of false identities and assumed names, and outline a story shrouded by a scandal that reached the upper echelons of His Majesty's Admiralty Court.

\section{The Menai and Captain Moresby}

The peace following the end of the Napoleonic Wars in 1815 was frustrating for many young naval officers, who felt they were now "condemned to inaction."5 One of the ships charged with blockading the island of St. Helena to prevent the escape of an imprisoned Napoleon Bonaparte was placed under the command of one such young officer in 1819-the future Admiral of the Fleet, Sir Fairfax Moresby. Soon after, the sixth-rate frigate $\mathrm{Menai}^{6}$

3 Moses D.E. Nwulia, The History of Slavery in Mauritius and the Seychelles, 1810-1875 (East Brunswick, NJ: Associated University Presses, 1981), 39-44.

$4 \quad$ Ibid., 46.

5 John Moresby, Two Admirals: Admiral of the Fleet Sir Fairfax Moresby and His Son, John Moresby (London: John Murray, 1909), 14.

6 T.A. Heathcote, The British Admirals of the Fleet, 1734-1995 (Barnsley, UK: Pen $\&$ Sword Books, 2015), 177; A British sixth-rate frigate numbered anywhere from 20 to 28 guns on the main artillery deck and measured from 450 to 550 tons. A ship like the 
was relieved of seaguard duty and ordered to sail for the Cape of Good Hope to assist with the establishment of a new settlement at Cape Colony. After the founding of Port Elizabeth, Sir Moresby was sent to Mauritius to "suppress the infamous slave trade carried on between Africa and the French colonies and Arab ports about the Persian Gulf."' As the senior naval officer at Mauritius, Captain Sir Moresby commanded the Menai until September 1824. During this period, Moresby patrolled the western Indian Ocean and Arabian Sea for slave ships and carried out "extensive surveys" of coastlines and islands, to the extent that he was "reduced to the lowest state of debility." 8

During his time as commander of the Menai, Sir Moresby completed the Moresby Treaty with the imam of Muscat in 1822, an agreement "designed to inhibit the shipment of slaves to French sugar plantations in the Mascarene Islands (Mauritius and Réunion)... [but] allowing the transport and sale of slaves along the western Indian Ocean rim to continue unabated...from southern Africa, to the west coast of India."9 A year later, Sir Moresby undertook a harrowing capture of a slave vessel named Camilla, securing 140 slaves and 10,000 Spanish dollars "despite [the ship] being protected by the local Arab governor." ${ }^{0}$ The biographer of Sir Fairfax Moresby, his son Sir John Moresby, described the Camilla as "a prize in all respects well worthy of her reputation...nor had rumor overstated her beauty Menai could have had 240 crew, including up to 19 officers. Brian Lavery, Nelson's Navy: The Ships, Men and Organization (Annapolis, MD: Naval Institute Press, 1989), 328.

$7 \quad$ Moresby, 19.

8 Moresby, 25.

9 Indian Ocean Slavery in the Age of Abolition, 9.

$10 \quad$ Heathcote, 178. 
and her sailing powers." ${ }^{11}$ Not present in his biography, however, is mention of one of his first captures as commander of the Menai not long after he was appointed senior naval officer at Mauritius.

\section{The Capture and Condemnation of the Industry}

Captain Sir Moresby, during patrol aboard Menai off the coast of Zanzibar in mid-1821, encountered the schooner Industry. ${ }^{12}$ Described as a vessel with certain notoriety as a slaver, the Industry was intercepted not incidentally but for "consequence of previous information" of having "violated the laws of Great Britain for the abolition of the slave trade." ${ }^{13}$ Indeed, the Industry may have been caught previously, nearly ten years earlier, when a ship called L'Industrie was captured in 1811 by the British sloops Race Horse and Astrea as it sailed from the coast of Madagascar to Mauritius with 208 enslaved Africans aboard. ${ }^{14}$ While it is virtually impossible to confirm if they are the same vessel or not, the accounts and correspondence given by authorities in Mauritius, including Deputy Registrar George Cabin, plainly validate the reputation of the Industry and that it was specifically sought by British patrols for its being "continually engaged in conveying slaves, sometimes to Mauritius and sometimes to [Île de] Bourbon (Réunion).”15

11 Moresby, 24.

12 The spellings Industry and Industrie are used interchangeably within the HCA volumes.

13 Account of George Augustus Nantz Cabin, 21 December 1821, HCA 35/6, The National Archives of the UK, London, 298.

14 Appeal from the Cape of Good Hope, 11 July 1813, HCA 42/444, The National Archives of the UK, London. 
The Industry was captured sometime in early- to mid-September 1821. The schooner was prosecuted at Port Louis by Captain Sir Moresby and condemned by George Smith, "esquire, barrister-at-law in the Court Official, Principal and Commissary General, and special Judge and President in the Court" at Port Louis, Mauritius on October $31,1821 .{ }^{16}$ The condemnation included "the vessel, her guns, boats, tackle, apparel, furniture, and goods, wares and merchandise laden therein, [and] also the persons in number, one hundred and [thirty], as scheduled...having been slaves at the time of their seizure." ${ }^{17}$ Also charged was the owner of the ship, Desiré Bataille, captain Jean Baptiste Mongin, and cargo supervisor Pierre Lange, each fined $£ 13000 \_£ 100$ for each slave captured. ${ }^{18}$

\section{The Crew of the Industry}

Just as the Industry was not unfamiliar to British authorities at Mauritius, neither was its crew. Upon discovery of correspondence onboard the schooner, British authorities had quickly determined the names given by the captain and cargo supervisor were not their true identities. Jean Baptiste Mongin was in fact Bernard Mongin, and Pierre Lange was a pseudonym given by Fortuné Dubignon. ${ }^{19}$ The former, Bernard, had engaged in the illicit trade of slaves before, and was captured as a mate aboard the St. Jacquet and as the commander of the Voyageur - each time swearing on oath to be Bernard

17 Ibid.

18 Cabin, HCA 35/6, 301.

19 Cabin, HCA 35/6, 300. 
Mongin, "subject of His Britannic Majesty" and inhabitant of Mauritius. ${ }^{20}$ Jean Baptiste Mongin, it was revealed in letters found in his possession, was his older brother and officer in the French service stationed at Bordeaux. Furthermore, testimony of his sisters who resided at Port Louis had recognized him as Bernard Mongin. ${ }^{21}$

Pierre Lange, alias of Fortuné Dubignon, was identified through evidence given by an informant. The court at Port Louis had found that he had "never...defeated his allegiance to the British government" and that it had "testimony [and] records that he participated with that same Mongin in the nefarious transactions of the Voyageur and that when he is now found embarking with this same individual onboard the Industry... it is impossible to draw any other conclusion than that he is a sharer in the crime of Mongin."22 The account of the Industry given by Cabin shows Mongin as the primary perpetrator, and that it is "impossible to perceive" that Desiré Bataille was the "director of the movements of the Industry" and that Bataille spoke "evidently of our (British) interests." ${ }^{23}$ Apart from the fines levied on Mongin, Bataille, and Dubignon, there is no mention in the Treasury report of any other punitive measures that may have been levied by the British government. The reason for this is that, at least in the case of Mongin, the verdict returned in the Vice Admiralty Court was not guilty. For his shipmates, the official record is inconclusive as their bills of verdict have been misplaced; it is reasonable to assume they too were found not guilty. ${ }^{24}$

Cabin, HCA 35/6, 299.

21 Ibid.

22 Cabin, HCA 35/6, 299-300.

23 Ibid.

24 Papers Relating to Slaves in the Colonies: Two Volumes - Contents of the First 


\section{Auction and Sale of the Industry and her Wares}

Upon condemnation of the Industry on October 31, 1821, a decree was handed down by His Majesty's Instance Court of Vice Admiralty at Mauritius to proceed with the auctioning of the ship and all effects found aboard. James Sanders Reader, the deputy marshal of the Court, was charged with carrying out the operation. ${ }^{25} \mathrm{He}$ includes in his report of his duties the careful cataloging of all costs incurred, as well as proceeds from the sale and subsequent distribution of those monies to concerned parties. The report, dated December 21, 1821, shows that the Industry was sold at Port Louis to a man named Samuel Nolbross, esquire and mariner, on December 1, 1821 for the sum of 5,310 Spanish dollars (denoted as $\mathrm{Sp}^{\mathrm{sh}} \mathrm{D}^{\mathrm{rs}}$ ). ${ }^{26} \mathrm{~A}$ table of the costs to British authorities, subtracted from the total revenue, are included at the end of his report:

\begin{tabular}{|l|l|l|}
\hline Charges & 127 \\
\hline Schedulating blacks @ 1 Dr each & 12 \\
\hline $\begin{array}{l}\text { Taking inventory and copies } \\
\text { Shipkeeping from 14th September to 1st Dec. 1821 inclusive, 3 Drs } \\
\text { per day }\end{array}$ & 237 \\
\hline $\begin{array}{l}\text { Cryer and trumpeter twice } \\
\text { Advertisement in Gazette and hand bills }\end{array}$ & 6 \\
\hline Commission on sale @ 2 1/2 per cent & 21 \\
\hline & 132.75 \\
\hline
\end{tabular}

and to whom they were awarded, notably the registrar of the Vice Admiralty, the crew of the Menai, and the Crown.

Volume (London: The Honorable House of Commons, 1828), 79, http://bit.ly/2JrBiHq.

25 Reader, HCA 35/6, 301.

26 Ibid. 
This is also the first mention of monies found aboard the Industry, in the sum of 4448.25 Spanish dollars. This is included in the table and brings the total revenue from the Industry incident totaling 9222.50 Spanish dollars: ${ }^{27}$

\begin{tabular}{|c|c|c|}
\hline \multicolumn{3}{|c|}{ Brig Schooner Industry in Account } \\
\hline \multirow[t]{4}{*}{$1821 \mathrm{Dec} 28^{\text {th }}$} & $\begin{array}{l}\text { To amount paid Charles Telfair, Esquire, his commission as } \\
\text { Registrar on the amount sales of the said Brig Schooner Industry }\end{array}$ & 238.71 \\
\hline & $\begin{array}{l}\text { To amount paid Richard Sholl, Esquire, purser of His Majesty's } \\
\text { Ship Menai by order of Captain Moresby }\end{array}$ & 712.86 \\
\hline & $\begin{array}{l}\text { To amount paid L.N. May, Esquire, proctor, his Bill by order of } \\
\text { Captain Moresby }\end{array}$ & 2263.50 \\
\hline & $\begin{array}{l}\text { To amount paid Charles Telfair his commission as Registrar on } \\
\text { Spanish Dollars found on board the Brig Schooner Industry }- \text { Spsh } \\
\text { Drs } 4448\end{array}$ & 222 \\
\hline 1822 May $1^{\text {st }}$ & $\begin{array}{l}\text { To amount paid Richard Sholl, Esquire, agents for captain, officers } \\
\text { and crew of His Majesty's Ship Menai, being the proportion award } \\
\text { to the seizors by sentence of Court } \\
\text { In } S \mathrm{p}^{\text {sh }} \mathrm{D}^{\mathrm{rs}} 2113.121 / 2 \text {, in paper } \mathrm{D}^{\mathrm{rs}} 779.59\end{array}$ & $2892.711 / 2$ \\
\hline \multirow[t]{2}{*}{ August $1^{\text {st }}$} & $\begin{array}{l}\text { To amount forwarded to England to the Registrar of the High } \\
\text { Court of Admiralty being the share awarded to the Crown by } \\
\text { sentence of the Court }\end{array}$ & $2892.71 \frac{1}{2}$ \\
\hline & & 9222.50 \\
\hline \multirow[t]{3}{*}{$1821 \mathrm{Dec} 28^{\text {th }}$} & $\begin{array}{l}\text { By amount received from J.S. Reader, Esquire, Deputy Marshal of } \\
\text { the Vice Admiralty Court being the net amount sales of the said } \\
\text { Brig Schooner Industry }\end{array}$ & 4774.25 \\
\hline & $\begin{array}{l}\text { By amount received from James Sanders Reader being Spanish } \\
\text { Dollars found on board the said Brig Schooner Industry }\end{array}$ & 4448.25 \\
\hline & & 9222.50 \\
\hline
\end{tabular}

While the inclusion of these tables is helptul and facilitates the understanding of how and to whom monies were dispersed, the auction and sale of the Industry appears unremarkable. Upon perusing accounts of other captures in these and other volumes of His Majesty's Treasury report books, the overall sum is relatively average. However, within these tables is mention of a man that presents another extraordinary instance in an otherwise ordinary story. 


\section{The Telfair Affair}

Charles Telfair was a colorful character. A renaissance man of sorts, he has been described as a "product of the Irish Enlightenment" - a botanist and naturalist, not unlike Charles Darwin in the Pacific or Hans Sloane in the Atlantic. ${ }^{28}$ First arriving at the Mascarene Islands in 1810 as a ship surgeon in the service of the Royal Navy, Telfair curated the botanical garden at Pamplemousses and held many government offices at both Réunion and Mauritius. ${ }^{29} \mathrm{His}$ many accolades include introducing the yellow Cavendish banana to Mauritius and discovering many plants, having a whole genus, Telfairia, named for him. ${ }^{30}$ Among the many government positions held at Mauritius, none were more consequential to the story of the Industry as serving as the personal secretary to Governor Farquhar and as registrar for the Vice Admiralty Court at Port Louis. ${ }^{31}$ As

28 Marc Serge Rivière, "From Belfast to Mauritius: Charles Telfair (1778-1833), Naturalist and a Product of the Irish Enlightenment," Eighteenth-Century Ireland 21 (2006): 125 .

29 Pico Iyer, "Mauritius's Past Enhances its Beauty," Financial Times, May 2, 2009, http://www.ft.com/cms/s/2/89bb0fbe-35dc-11de-a997-00144feabdc0.html. Page has since been deleted, only access is now through the Internet Archive at https://web. archive.org/web/20090605235330/http://www.ft.com/ cms/s/2/89bb0fbe-35dc-11dea997-00144feabdc0.html.

30 Elizabeth Findlay, "A Colonial Conundrum: Boy with Sulphur-Crested Cockatoo," Melbourne Art Journal, no. 3 (2008), 5, https://emajartjournal.files.wordpress. com/2012/08/findlay.pdf; M.O. Akoroda, "Ethnobotany of Telfairia occidentalis (Cucur bitaceae) among Igbos of Nigeria," Economic Botany 44, no. 1 (1990): 29.

31 Charles Telfair, Some Account of the State of Slavery at Mauritius Since the British Occupation in 1810: In Refutation of Anonymous Charges Promulgated Against Government and That Colony (Paris: H. Lamirault, 1830), 11. First edition access provided by Internet Archive, complete with handwritten front matter, https://ia802606.us.archive.org/18/ items/someaccountofsta00telfrich/someaccountofsta00telfrich_bw.pdf. 
registrar, Telfair would have overseen all official records and financial transactions on Mauritius. As such, his office was made aware of the capture of the Industry in early- to mid-September 1821 and was responsible for the chronicling of events as well as the sale and disbursement of monies related to the captured schooner.

Captain Sir Moresby alerted customs and treasury officials in May 1823 that Charles Telfair had "retained five percent of the money found on the persons captured onboard the Industry slave trader," and implores "their Lordships to take steps to make Mr. Telfair refund to the captors the illegal charge on their moiety of the prize as well as to the Crown on the other moiety." ${ }^{\prime 2}$ Telfair responded quickly to the accusation posited by Moresby, replying on May 15 from his office in Port Louis that he was appealing to the "proper authorities in England, who will decide more equitably upon the particular case, when the statements of both sides shall be before them." ${ }^{33} \mathrm{He}$ is defiant in his tone, adding that he would "cheerfully obey any orders [he] may receive... but until that decision convinces [him to] the contrary, [he] must still consider the money in question as a part of the original seizure." ${ }^{34}$ Customs officials responded in kind later in 1823, stating that despite the "documents [being] regular," it was "advisable to suspend the payment of bounties" 35 until it could be discovered what had occurred.

What followed was a court investigation into whether Charles

32 Letter from Fairfax Moresby, 12 May 1823, HCA 35/6, The National Archives of the UK, London, 246-47.

33 Letter from Charles Telfair, 15 May 1823, HCA 35/6, 248.

$34 \quad$ Ibid.

35 Letter from G. Harrison, December 1823, HCA 35/4, 2. 
Telfair had embezzled or otherwise improperly acquired the funds in question. A June 30, 1825 letter to the Lords Commissioners of His Majesty's Treasury from an advocate of the Admiralty stationed in Vernon Place at Bloomsbury Square, London issued a verdict. It was found that Telfair had given a faulty statement and that "the charge of five percent made by Mr. Telfair...[was] excessive," and that "His Majesty's and the Advocate of the Admiralty do not advise any proceedings to be instituted on behalf of His Majesty, [only the] regular mode of recovering from him the amount he has improperly charged."36 The letter goes further, adding perhaps why no further discipline were to be brought upon Telfair: "I am not aware that any regular table of fees for the Vice Admiralty Court at the Mauritius has been sanctioned by authority in this country," adding "two pence on the pound was recommended...to be allowed... at the Cape of Good Hope" and that "there does not appear any reason for allowing larger fees... at the island of Mauritius." 37 The advocate concludes that Telfair should have only taken two pence on the pound, or two percent, rather than the five percent he took in late 1821.

The letter sent by Telfair to Moresby in response to the charge against him certainly shows that he believed he was due the extra money taken from the 4448.24 Spanish dollars seized by Moresby and his crew following the capture of the Industry. According to the investigation, five percent was ultimately an arbitrary value that Telfair had settled upon.

37 Letter from Advocate W.R., 30 June 1825, HCA 35/6, 253. 
There is no mention of this incident, Captain Sir Moresby, nor any financial impropriety in Some Account of the State of Slavery at Mauritius, the memoir of Telfair that describes his governmental work at Mauritius during the 1810s and 1820s. Instead, Some Account of the State of Slavery at Mauritius reads as an apology for the actions of his superior, Governor Farquhar, who had responded with hesitation to the abolition of slavery.

\section{Conclusion and Aftermath}

The capture of the Industry is unique and compelling for three reasons. The crewmembers that commanded the ship and imprisoned the captives aboard it, Bernard Mongin and Fortuné Dubignon, had substantive pasts in the slave trade and sought to avoid the consequences of their actions by masquerading as Frenchmen, who could not be held fully accountable by British authorities. The 4448.24 Spanish dollars found aboard their vessel were improperly handled after seizure by none other than the registrar of His Majesty's Vice Admiralty Court at Mauritius, who consciously took a larger moiety than he was due. The fallout of that fateful decision would reach His Majesty's Advocate and the Advocate General of the Admiralty and spur a new policy that extended to all future slave ship captures under the purview of the Vice Admiralty Court at Mauritius. And, perhaps whimsically, the story of the Industry intersects two of the more consequential men of the nineteenth-century British colonial Indian Ocean space-Fairfax Moresby and Charles Telfair.

Though not the heroic capture of the Camilla or the lucrative seizure of the Succès, the Industry is a story of redemption for young 
Fairfax Moresby. Cast out from Port Elizabeth after missing out on the excitement of the Napoleonic Wars, Moresby quickly found favor as a successful slaver hunter in the Indian Ocean. The triumph of securing embezzled funds from Telfair for his own men on the Menai would appear to not go unnoticed by the Admiralty. Moresby quickly rose in rank in the following decades, awarded the command of larger ships-of-the-line Pembroke and Canopus, and assuming the ranks of Admiral of the Blue in $1862,{ }^{38}$ Vice-Admiral of the United Kingdom in $1869,{ }^{39}$ and Admiral of the Fleet in $1870 .{ }^{40}$ The capture of the Industry is as momentous to Fairfax Moresby as it is to the wider incidence of the African slave trade across the Indian Ocean, and stands as a distinctly human story of truth, lies, and misdeeds in a time both temporally and spatially distant from the present.

38 "Admiralty," London Gazette, May 20, 1862, https://www.thegazette.co.uk/ London/issue/22627/page/2615.

39 "Whitehall, July 17, 1869," London Gazette, July 20, 1869, https://www.thegazette.co.uk/London/issue/23518/page/4063.

40 "Admiralty," London Gazette, February 1, 1870, https://www.thegazette.co.uk/ London/issue/23582/page/598. 


\section{Bibliography}

"About HCA 35." HIST 429 handout. The National Archives of the UK, 2017.

"Admiralty." London Gazette, February 1, 1870. https://www. thegazette.co.uk/London/issue/ 23582/page/598.

"Admiralty." London Gazette, May 20, 1862. https://www.thegazette.co.uk/London/issue/ 22627/page/2615.

Akoroda, M.O. "Ethnobotany of Telfairia occidentalis (Cucurbitaceae) among Igbos of Nigeria." Economic Botany 44, no. 1 (1990): 29-39.

Allen, Richard Blair. European Slave Trading in the Indian Ocean, 1500-1850. Athens, OH: Ohio University Press, 2014.

Alpers, Edward. Indian Ocean in World History. New York: Oxford University Press, 2013.

Alpers, Edward. "The Other Middle Passage: The African Slave Trade in the Indian Ocean" in Many Middle Passages: Forced Migration and the Making of the Modern World. Edited by Emma Christopher, Cassandra Pybus, and Marcus Rediker. 
Berkeley: University of California Press, 2007.

Anderson, Clare. Subaltern Lives: Biographies of Colonialism in the Indian Ocean World, 1790-1920. Cambridge, UK: Cambridge University Press, 2012.

Colomb, John Charles Ready. Slave-Catching in the Indian Ocean: A Record of Naval Experiences. New York: Negro Universities Press, 1969.

Findlay, Elizabeth. "A Colonial Conundrum: Boy with Sulphur-Crested Cockatoo." Melbourne Art Journal, no. 3 (2008). https://emajartjournal.files.wordpress. com/2012/08/findlay.pdf.

Heathcote, T.A. The British Admirals of the Fleet, 1734-1995. Barnsley, UK: Pen \& Sword Books, 2015.

Indian Ocean Slavery in the Age of Abolition, edited by Robert W. Harms, Bernard K. Freamon and David W. Blight. New Haven, CT: Yale University Press, 2013.

"L'Industrie." Appeal from the Cape of Good Hope. HCA 42/444. The National Archives of the UK, London.

"Industry." Slave Trade Adviser to the Treasury report book, HCA 35/4. The National Archives of the UK, London. 2, 
$133-134$.

"Industry." Slave Trade Adviser to the Treasury report book, HCA 35/6. The National Archives of the UK, London. 246-253, 297-303.

Iyer, Pico. "Mauritius's Past Enhances its Beauty." Financial Times, May 2, 2009. https://web.archive.org/ web/20090605235330/http:/www.ft.com/ cms/s/2/89bb0fbe-35dc-11de-a997-00144feabdc0.html.

Lavery, Brian. Nelson's Navy: The Ships, Men and Organization. Annapolis, MD: Naval Institute Press, 1989.

Moresby, John. Two Admirals: Admiral of the Fleet Sir Fairfax Moresby and his Son, John Moresby: A Record of Life and Service in the British Navy for a Hundred Years. London: John Murray, 1909.

Nwulia, Moses D.E. The History of Slavery in Mauritius and the Seychelles, 1810-1875. East Brunswick, NJ: Associated University Presses, 1981.

Papers Relating to Slaves in the Colonies: Two Volumes - Contents of the First Volume. London: The Honorable House of Commons, 1828. 
Rivière, Marc Serge. "From Belfast to Mauritius: Charles Telfair (1778-1833), Naturalist and a Product of the Irish Enlightenment." Eighteenth-Century Ireland 21 (2006): 125-144.

Schnepel, Burkhard and Edward Alpers. Connectivity in Motion: Island Hubs in the Indian Ocean World. New York: Palgrave Macmillan, 2017.

Telfair, Charles. Some Account of the State of Slavery at Mauritius Since the British Occupation in 1810: In Refutation of Anonymous Charges Promulgated Against Government and that Colony. Paris: H. Lamirault, 1830.

“Whitehall, July 17, 1869." London Gazette, July 20, 1869. https://www.thegazette.co.uk/London/issue/23518/ page/4063. 
Paul J Michaels 


\section{AUTHOR BIOGRAPHY JILL WILSON O'CONNOR}

Jill Wilson O'Connor is an alumnus of Cal Poly, San Luis Obispo with a Bachelor of Science degree in Natural Resources Management and a current candidate for a Master's degree in History. She has extensive experience as an environmental consultant analyzing potential ecological impacts from proposed development and transportation projects. Her master's thesis considers historical changes to vegetation alliances relative to agricultural land uses within the coastal prairie ecosystem at Cal Poly's Swanton Pacific Ranch. 


\section{Slaving Vessel Soleil (Tigre): 1825 Voyage from Port of Mahe, Seychelles Islands to St. Augustin's Bay, Madagascar}

JILL WILSON O'CONNOR

\section{The Voyage and Capture of the Soleil (Tigre)}

This paper addresses the French slave ship Soleil (also known as Tigre) which was condemned by the British government at the end of the first quarter of the nineteenth century as part of the United Kingdom's enforcement of, and authority under, the Abolition of the Slave Trade Act, 1807. Information regarding the Soleils departure and capture locations is obtained from documentation and correspondence of the Instance Court of Vice Admiralty contained in the Report Book HCA 35/8 of the Slave Trade Advisor to the Treasury (Report Book) held in the National Archives of the United Kingdom. ${ }^{1}$ While the information in the Report Book does not reveal details regarding the origins and livelihoods of the slaves aboard the 1 The National Archives of the UK (TNA), HCA 35/8, pp 144-155. 
Soleil before they were captured and their freedoms ended, nor their dispositions after the ship was seized and condemned by the British crown, I argue that the upheaval and detriment forced on their lives can be fairly envisioned based on available supporting information. Specifically, oral and written narratives from former slaves and other witnesses as well as statistical data regarding slave voyages during those centuries can provide a clarifying lens into a group of individuals that had native kinship and fictive networks and livelihoods torn apart and never to be rebuilt, and who were subjected to abhorrent truths about inhumanity as their individual freedoms were stolen.

The Brig Soleil (Tigre) was outfitted for slaves and departed from the Port of Mahe (sometimes spelled Mahi in the Report Book correspondence), a British port in the Seychelles Islands in the Indian Ocean, east/southeast of the coast of Africa. The ship was seized by the British Royal Navy in May 1825 at St. Augustin's Bay on the southwest coast of the island of Madagascar, an estimated trip distance of 1,500 to 1,800 statutory miles. The Royal Navy ship that arrested and seized the Soleil at St. Augustin's Bay was the Leven, captained by William Fitzwilliam Owen, Esquire. ${ }^{2}$ The record documents did not specify where the slaves were procured, if other than the Seychelles, nor does the documentation identify the slave ship's destination. The Record Book entries for Soleil/Tigre made no indication regarding any problems or other details of the capture, nor any physical information about the ship itself. According to the HCA entry book correspondence, the brig was "carried" to Port Louis on the Island of Mauritius, where proceedings were initiated in 
the Vice Admiralty Court. This description may have meant that the ship was towed by the Leven around the south end of Madagascar Island and up the east coast of the island and then to Mauritius, however, further details to clarify the exact method of what was meant by carrying the slave ship were not disclosed.

Condemnation of the ship and its cargo was confirmed by the Instance Court of Vice Admiralty on July 28, 1825 under a declared lawful seizure process by the Leven. The Vice Admiralty court directed the Soleil and its cargo, i.e., furnishings, goods, wares, guns and tackle, to be sold and the proceeds divided into two equal portions: one to go to the British king, his heirs and successors, and the other portion to go to the officers and crew of the Royal Navy ship Leven as the bounty for capturing and bringing in the slave ship. ${ }^{3}$ The Record Book includes correspondence from Leven's Captain Owen dated August 4, 1825, on behalf of Navy agent W. Joseph Woodhead for the officers, crew and captain, in which he confirms the lawful seizure and detainment of the Soleil (Tigre) at St. Augustin's Bay, Madagascar, with a cargo of 152 slaves on board, six of whom were deceased, and that the Soleil had been fitted out and equipped and dispatched from the Port of Mahi (Mahe) for the purpose of being in the slave trade, contrary to the legal statute (i.e., the Abolition of the Slave Trade Act, 1807). A certificate from W. Archibald LeBlanc, Acting Collector of Customs at the Mauritius Vice Admiralty, confirms that as provided in Section 5.G.4.C.14 Captain Owen is entitled to the bounties of ten pounds per slave, or a total of 1,460 pounds for the 146 slaves that survived the journey, and that it may 
be legal to compensate Owen for the deceased slaves as well. However, per William Rothery's report in March 1826, he posits that the application for the bounty payment is premature and advises the Lords Commissioners of the court to hold off on the bounty payment until the appeal period of ten months has elapsed and until an accounting of the vessel's proceeds is made. ${ }^{4}$ No correspondence regarding the completion of the final bounty payment was found in the HCA 35/8 book.

Record Book HCA 35/8 does not specify the names of the Soleils captain or crew members. However, according to the court documents of the case proceedings the ship was navigating under the flag of Portugal when it was seized, causing some confusion. A letter of protest/declaration had been submitted to the judge by the French consular agent on behalf of parties interested in the ship and its cargo; it seems logical that the interested parties would have been the Soleils captain and crew, although the HCA report book does not specify that information. Nonetheless, the correspondence and other evidence furnished by the parties through their Consul was reviewed by the judge who determined that although the ship had been flying the Portuguese flag, it was in fact property of French subjects and that the flag had been improperly used to "cover the transaction... and that no part of the vessel was Portuguese." The remaining evidence was examined by the judge and determined to be a vessel "fitted out, equipped and dispatched in and from the Port of Mahe ... for the purpose of being employed in the slave trade," and actually did engage in the slave trade, and "had at the time of its 
seizure by the Leven a cargo of 152 (one hundred fifty two) persons kept as slaves, and as such was subject to confiscation and condemnation." 5

A "Schedule of Slaves" is contained in Record Book HCA $35 / 8$ which states that a total of 152 slaves were on board when Soleil was captured at Madagascar. The slaves are assigned an individual identification number in the Schedule. There were 92 men (approximately $60 \%$ of the total group), 15 women (10\%) and 45 children (30\%); slavers considered anyone less than 10 years to be a child.6 The six slaves who had perished included: Martindie, a 15-year old man (No. 77), Pellallaye, a 9-year old boy (No. 120), Nancambie, a 21-year old woman (No. 145), Marroselah, a 37-year old man (No. 147), Teckerecoupia, a 20 -year old man (No. 148), and Moussaloumah, a 14-year old man (No. 152). ${ }^{7}$ The 152 captives ranged in age from 6 to 37 years old, with the majority in their teenage years. Each slave had either a letter tattoo or a sear or scar on various locations on their bodies; the letters included S, SS, O, Z, FO, B, U, as well as several unique images as drawn in the Schedule. Since there were multiple slaves with the same letter tattoos, they may likely have been the brand made during the processing by the slavers to designate the receiving plantation or other slave ownership or destination. The 146 enslaved who survived, once emancipated as part of the condemnation proceedings, were delivered to the authorities in Port Louis on Mauritius as part of the British monarch's half of the distributed proceeds according to the Record Book correspondence. ${ }^{8}$

5 TNA, HCA 35/8, pp 152-153.

6 Robert Harms, The Diligent, (New York: Basic Books, 2002), 247.

7 TNA, HCA 35/8, pp 145-150.

$8 \quad$ Ibid.,p 155. 


\section{The Voyage in the Context of the Euro-African Slave Trade}

The voyage of the Soleil was not unusual having been initiated in the Indian Ocean islands before its seizure by the British Navy, however, that region was not one of the most common areas of departure for slaving vessels, as discussed subsequently. As related to the background of the overall slave trade, this voyage was one of about thirty-five thousand slave voyages during the period of the sixteenth through nineteenth centuries in which approximately twelve million captives were taken from the continent of Africa to slaving plantations and other destinations in the Americas. A small number in the sixteenth century were taken to ports along the West African coast for domestic slave use there, however, the overwhelming majority of captives were transported west across the Atlantic Ocean to European colonies during these centuries. ${ }^{9}$

Historian Robert Harms provides a detailed look into one particular voyage in 1731-1732 of a French grain ship-turned slaving vessel from the journal of the crew's first lieutenant, Robert Durand in The Diligent. According to Harms, the slave trade was constantly in flux, changing continuously due to diverse national and local objectives. ${ }^{10}$ In the mid-fifteenth century, Portuguese explorer Joao Hernandes became familiar with the peoples along the West Coast of Africa and learned that there were existing markets there from which Europeans could obtain slaves and gold in exchange for European goods.

$9 \quad$ "Trans-Atlantic Slave Trade Database," Emory University, accessed December 5, 2017, http://www.slavevoyages.org/summarystatistics. 10 Harms, The Diligent, xiv. 
The first slaves obtained by Portuguese traders were used in Portugal and Spain as servants to nobles.

The Portuguese then developed sugar plantations on two uninhabited islands off the coast of West Africa, Sao Tome and Principe, and slaves from Africa were used there as those plantations became the prototype for plantation economies in the Americas. ${ }^{11}$ Christopher Columbus brought sugar cane to the Americas on his second voyage in 1493 where demand for African labor was high after the indigenous peoples suffered catastrophic death rates due to lack of immunity to European germs. ${ }^{12}$

European dominance in the slave trade changed over time, with shifting legal treaties and contracts that specified the country that would ship slaves to other European colonies. Initially, Portugal held sway in the late fifteenth and sixteenth centuries, and then in the seventeenth century the Dutch challenged the Portuguese, with the Dutch West India Company gaining the assiento treaty that gave them exclusive rights to transport slaves to Spanish and Dutch plantations. ${ }^{13}$ Britain and France got involved in the trade later in the seventeenth century to supply labor for their Caribbean colonies including Jamaica, Barbados, North America, and Saint-Domingue, Martinique, Guadalupe and French Guiana, respectively. The French did not import slaves to work in France because of a common law held over from the Roman era in which any slave that arrived in France was automatically free. ${ }^{14}$

11 Harms, The Diligent, xv.

12 Ibid., xiv-xv.

13 Ibid., xv.

14 Ibid., xv-xvi. 
The source locations in Africa where people were captured varied over time, particularly in the inland areas. In the sixteenth century they were mostly taken from the Congo and Angola region. Captives were also taken from West Africa, particularly the Gold Coast, Senegambia, Bight of Benin and the Bight of Biafra, and the latter produced the majority of West African slaves in the first half of the seventeenth century. ${ }^{15}$ The eighteenth century was the peak of the transatlantic slave trade activity, with over $85 \%$ of the slaves transported to the New World during that period to serve what Harms describes as an enormous expansion in the trade. That century also saw a change in the type of commercial organization of the trade, from mostly government-sponsored monopoly companies, such as the Senegal Company, the Royal African Company and the Dutch West India Company, to allowance of privately-underwritten slavers. This shift was due largely to the major increase in demand for quantities of slaves in the New World plantations which the monopoly companies could not satisfy alone. ${ }^{16}$ According to Harms, there was no overarching global entity that drove the Atlantic slave trade because different local interests were at work, e.g., events and rivalries, on three continents that participated in slavery. ${ }^{17}$

Harms explains that for local governments investing in slaving it was seen as an economic venture, not a moral one. For example, for the City of Nantes, France, the home port of the subject ship, the Diligent, the mayor saw slave trading as an opportunity to ex-

15 Ibid., xvi.

16 Harms, The Diligent, xvii- xviii.

17 Ibid., xix. 
pand international commerce for the city. ${ }^{18}$ Other reasons were used as justification for putting humans in bondage for sale. For example, the mayor of Nantes' view was that slavery was doing a service to rescue Africans from "error and idolatry," procuring them a path to salvation. In addition, being ignorant of African geography, the mayor determined that a fictional place he understood to be "Nigritie" was overpopulated such that relieving the area of some of the population through captivity would prevent others there from starvation. ${ }^{19}$ The economic driver behind the slave trade was reflected in years of debate between mercantilists and capitalists in the early eighteenth century. Competition between slaving nations increased as they were motivated to find more and more slaves to work the plantations and produce sugar, cotton, indigo and other goods, as the products the slaves created were the source of profits, not the slave trade itself. ${ }^{20}$ The mercantilist view is exemplified by De Gaullitzer in the late seventeenth century who argued that, for the French, a "multitude of slaves is necessary to compete successfully with the English, Dutch and Portuguese in the production of plantation staples and in navigation." ${ }^{21}$ In the story of the Diligent, Harms describes the cargo and supplies that were loaded onto the ship in Vannes,

France which would have been typical for a slaving voyage such as the Soleil took. Cargo included materials to trade for African captives: several different types of cotton cloth textiles, cowry shells for currency (along the coast of West Africa), and crew supplies in-

18 Ibid., 13.

19 Ibid., 19-20.

20 Harms, The Diligent, 37.

21 Ibid., 37. 
cluding guns, ammunition, brandy, smoking pipes, as well as Swedish iron, food stuffs, drinking water (rule of thumb would be three quarts of water per person/per day), wines, and firewood. ${ }^{22}$ Items specific for the slaves included a special stove and oven for cooking for the slaves' food during the Middle Passage across the Atlantic Ocean, ankle irons that locked two slaves together, muskets, pistols, swords, cannon balls and fuses for the cannons, and other weaponry in case of slave revolts and/or attacks by pirates. Food stuffs included hard biscuits, flour, fava beans, and minor amounts of ham and cheese. The beans were used to make a daily gruel for both the slaves and crew. ${ }^{23}$

Whereas in the early era of the trade in the late fifteenth to mid-sixteenth centuries about twelve thousand slaves were imported by the Portuguese into the Gold Coast area of West Africa for domestic work there, by the eighteenth century, slaves were being exported to the Americas for foreign plantation work, a dramatic shift in slave trading operations. ${ }^{24}$ Also in the eighteenth century, forts which were initially built in the prior century to store gold for cargo ships by the Dutch, British, and other European slaving countries became holding cells for slaves awaiting deportation. ${ }^{25}$ Rival African empires vying among themselves for control and expansion in the interior regions behind the forts, e.g., the Asante, Whydah, and Dahomey kingdoms, traded captives for guns and ammunition from

22 No indication of the destination of the Soleil's slave voyage was noted in the Report Book, TNA, HCA 35/8, pp 142-161. However, if it had been destined to West Africa cowry shells may have been included in the cargo.

23 Harms, The Diligent, 82-83.

24 Ibid., 135.

25 Harms, The Diligent, 125,135. 
Europeans. For example, around $1730 \mathrm{CE}$, the Dutch sold as many as 180,000 weapons and ammunition to African states in the Gold and Slave Coast areas. ${ }^{26}$ As an example of local African participation in the transatlantic trade, the small kingdom of Whydah (not more than 100,000 people) played a significant part in exportation of captives from the West African coast in the early eighteenth century; Wydah reportedly exported between sixteen and twenty thousand captives, more than the other West African ports combined. Further, during the first quarter of the eighteenth century, Whydah supplied over forty percent of all exported slaves during the transatlantic slave trade. The slaves that were acquired were often captives from local wars, or people selling relatives if they were poor and hungry, or those owing a debt. ${ }^{27}$

Life for new slaves was shocking and disorienting as they were suddenly alienated from their familiar kinship groups and communities, becoming commodities for sale rather than unique human beings. Harms posits that the collection of slaves on any given day were likely to be from various ethnic groups, further infusing their sense of separation from familiar kin and kith.

During the initial process of being rounded up for holding prior to departure was the first time that most native Africans saw white people, e.g., the European slavers, which was additionally fear-inducing since local rumor said that whites were cannibalistic. ${ }^{28}$ In addition, some slaves from the interior regions had never seen the ocean before being brought to the coastal slaving departure points, and, 26 Ibid., 135.

27 Ibid., 159, 246.

28 Ibid., 246-248. 
therefore, were likely to also not know how to swim. Slavers preferred young captives for slave work, ten to fifteen years old, and some merchants would shave and polish with pumice stone captive adult males to make them appear as young as possible for the buyers. Regarding gender ratios, Harms describes a Portuguese slaver's opinion in the early eighteenth century of three males to one female as being preferred, not understanding the value of females for field work. ${ }^{29}$

Captives underwent humiliating physical examinations prior to departure, being stripped naked and poked and prodded all around; they were then branded like livestock. They were imprisoned in warehouse-like structures at the forts, closely packed together as more and more slaves were processed and the holding rooms filled without sufficient ventilation. They were given two starch-laden meals per day without protein or fruit, contrary to their much more nutritious diets when they were free, which included generous amounts of meats and citrus. Aboard ship, a similar feeding routine was implemented, with a tasteless gruel-soup mixture of fava beans, millet, peas or flour served in buckets to the slaves twice a day, with very little variation or seasonings.

Therefore, the slaves on the Diligent found the gruel unpalatable to the degree that some refused to eat, for which they were physically punished. Scurvy invariably disabled or killed slaves aboard ship due to the limited diets which reserved any smaller amounts of provisioned proteins and fruits for the officers and crew, particularly when food stuff supplies dwindled due to extended trip lengths or bad weather. ${ }^{30}$

29 Harms, The Diligent, 247, 252.

30 Ibid., 250, 308, 317. 
Slave ships were modified especially for transporting captives in order to give the crew the ability to implement as much control and subjugation as possible and to minimize rebellions. Using the changes made to the Diligent as an example, the following design modifications were likely to be the case for ships such as the Soleil, to create a type of prison ship, per Harms. Front and rear decks were partitioned off from each other to separate the women and men, passageways were narrowed, vertical barriers were installed both on the exterior and interior to separate the quarter deck from the main deck to provide a safe place for crew in case of a slave rebellion. ${ }^{31}$ Below the main deck a special slave deck was built where the slaves would sleep during the night; this deck was tantamount to a sardine can with slaves literally packed cheek-to-jowl, with individual spaces measuring about one foot wide and five feet long. Slaves either had to lie on their sides or sit folded with knees up depending on their space location on the deck. Smaller ships also aggravated the conditions on the slave deck by packing more slaves in a smaller lower deck space than on other ships. ${ }^{32}$

No information regarding the size of the Soleil (Tigre) was indicated in the Record Book so even though other slaving vessels were known to have carried over 200 or 300 slaves, nonetheless, the tight quarters on the slave deck would have been torturous and difficult to endure for Soleils 152 captives in transport.

32 Ibid., 262-263, 305. 
The discomfort of lying on rough boards in tight spaces on a crowded deck was aggravated by the stifling stench from hundreds of bodies in a compact space with little ventilation further exacerbated by a tropically warm climate. As one example of the abominable conditions they suffered with, the men were shackled in pairs so that when one moved the other had to as well, tripping over other captives and causing anger and frustration when they needed to get up to relieve themselves. ${ }^{33}$

The multiple elements of poor diet, extreme discomfort below decks, illness, and inhumane conditions involved with transporting captive Africans, made worse by a lengthy journey across the Atlantic Ocean with no land in sight for two to three months, justifiably led to feelings of severe anger and acts of rebellion, extreme sadness and depression, mental instability, and thoughts of suicide among the slaves. As Harms notes, the mortality rate overall for the entire Atlantic slave trade during the first quarter of the eighteenth century was sixteen percent $(16 \%)$ of the captives. ${ }^{34}$ The Soleils voyage lost $3.9 \%$ of the slave cargo by comparison, however, it was a shorter trip (at least to St. Augustine wherein it was seized by the British) than those that made complete journeys to their slaving destinations.

The most difficult portion of the slave voyages was the Middle Passage, the crossing of the Atlantic from African shores and offshore islands to plantation destinations in the Americas. According to data from the Trans-Atlantic Slave Database, the average trip through the

$34 \quad$ Harms, The Diligent, 307, 317. 
Middle Passage took sixty and one-half (60.5) days using a sample size of 7,069 voyages. ${ }^{35}$

\section{Slave Voyage Data Comparison}

The data in Emory University's Trans-Atlantic Slave Trade Database accounts for voyages that reached American (South, North and Caribbean) and/or African slave destinations, and as such the data includes both embarkations from African regions of collection and disembarkations at slaving destinations. Therefore, the data pertaining to the number of slaves on each recorded ship among the approximately 35,000 voyages in the database represent full trips, unlike the ones such as the voyage of the Soleil which were interrupted and confiscated by the British prior to reaching the intended slave reception port in the Americas. However, this seminal database provides extremely valuable statistical information with which comparative analysis can be made for arrested voyages in terms of departure locations and routes, quantities of embarkations and timeframes by region and relative route levels, among other information.

The embarkation location of the Soleil out of the Seychelles Islands was one of the less frequent ports of departure for slave voyages during the first quarter of the nineteenth century; the majority of slave ships departed from West Central Africa and the Bight of Biafra. According to Emory University's slave voyage data, during the decade of 1821-1830 approximately 121,200 slaves embarked (were carried off) from the Southeast Africa and Indian Ocean Islands region out of an estimated total of 855,800 from all departure regions

35 "Trans-Atlantic Slave Trade Database," Emory University, accessed December 5, 2017, http://www.slavevoyages.org/summarystatistics. 
that decade, or $14.2 \%$

of the slave embarkations recorded for that ten year period. ${ }^{36}$ Although the amount of slave embarkations from the Southeast Africa and Indian Ocean Islands region (which includes the southeastern states of mainland Africa, Madagascar, the Seychelles and other small islands in the archipelago) shows as the third largest for that particular decade, many more embarkations came from West Central Africa with 442,000 slaves and the Bight of Biafra with 164,000 slaves. For comparison, the total number of slaves that were carried off during the entire slave trade (1501-1870 CE) is about $12,521,500$ according to the database, thus, the embarkations from the region that included the Soleils voyage between the Seychelles and Madagascar during that decade represented less than one percent $(00.97 \%)$ of all of the slaving voyage embarkations documented to date. For another comparison, during the quarter-century period of 1800-1825, 182,338 slaves were carried off from the Southeast Africa and Indian Ocean Islands region, or $1.46 \%$ of all slave trade embarkations. ${ }^{37}$ For the entire slave trade period of the beginning of the sixteenth to end of nineteenth centuries, roughly 543,000 slaves were carried off from the Southeast Africa and Indian Ocean Islands region, compared with the major embarkation regions of West Central Africa and St. Helena (5.7 million slaves),

Bight of Benin, Bight of Biafra and the Gold Coast (4.8 million) and Senegambia, Sierra Leone and the Windward Coast (1.5

November 11 and December 5, 2017, http://www.slavevoyages.org/assessment/ estimates.

Ibid. 
million). ${ }^{38}$

The Soleils voyage was interrupted by the Royal Navy's seizure of the vessel and cargo off Madagascar and its ultimate destination was not specified in the report books, however, given the time period of its journey, it is most likely that its destination would have been one of the more frequent slave-landing locations per the database, which included southeast Brazil, the Americas, including Cuba and the Caribbean islands, and Sierra Leone. The highest number of slaves purchased in the Southeast Africa and Indian Ocean Islands (if Soleil's slaves were purchased in the area they embarked from) were delivered to southeast Brazil. ${ }^{39}$ The ratio of men, women, and children on the Soleil was roughly consistent with the overall percentages for the entire slave trade, which was 64.6\% male (Soleil 60\% men), $14 \%$ women (Soleil 10\% women) and 21\% children (Soleil 30\% children); the Soleils slave population had more children and less women than the average. ${ }^{40}$

\section{Slave Experiences}

The experiences of the slaves on board the Soleil would likely have been similar to those of other slaves during the era of the transatlantic slave trade, particularly while at sea and at work on plantations and other sites for slave owners. The following example is provided from a narrative by former slave Olaudah Equiano as documented in "Documenting the American South: the North American 38 "Trans-Atlantic Slave Trade Database," Emory University, accessed December 5, 2017, http://www.slavevoyages.org/assessment/estimates/maps. 39 "Trans-Atlantic Slave Trade Database," Emory University, accessed November 11, 2017, http://www.slavevoyages.org/voyage/search. 40 Ibid. 
Slave Narratives Database." 41 While the specifics of each slave's experience are unique, the overarching oppression of the conditions of enslavement during this transatlantic era contains common elements that all those that found themselves enslaved would have likely experienced.

Olaudah Equiano was born in 1745 in Essaka, an interior region of sufficient distance from the capital of Benin such that he and his people were unfamiliar with white Europeans, the ocean, and ship-going. He was kidnapped from his home territory with his sister when he was eleven years old, and they were taken on a six to seven month-long arduous journey through various interior African states before arriving at an unnamed coastal embarkation point, possibly the Bight of Benin. He describes his horror when being brought aboard ship of seeing white Europeans for the first time and their treatment of his fellow slaves who were chained together while still in port. For example, those slaves that dared refuse to eat were punished by whipping, as were those who tried to jump overboard. Olaudah was also flogged for refusing to eat unfamiliar food stuffs from fearsome white men with red faces who he was certain would eat him. He describes the demeanor of the chained captives as sad and dejected.

Olaudah provides a thorough and detailed description of the extreme stench on the lower slave deck; he became sick from the December 4, 2017, accessed December 5, 2017, http://docsouth.unc.edu/neh/ chronautobio.html, http://docsouth.unc.edu/neh/equiano1/equiano1.html,1215. 
smell and depressed from the crying of the other slaves forced to confinement there, sometimes for days at a time with no fresh air.

He says he had never seen or experienced such a manner of cruelty as those of the white crewmembers; for example, one slave was mercilessly flogged to the point that he died of the injuries and was tossed overboard. Olaudah's fear of the whites therefore increased and was constant, not only because of their inhuman treatment of the captives but also because of all of the unfamiliar things he was being exposed to that he could only think were caused by magic, such as seeing another ship sailing into the port with full sails up and stopping, seemingly unexplainably. Although he was spared being forced to stay below decks as often as most of the other slaves, apparently because he was perpetually sick from the stench and near suffocation compounded by the tropical heat, he nonetheless came to contemplate death as potentially preferable to end the misery of the conditions. Providing numerous examples of cruel and incomprehensible treatment of the slaves by the crew in his detailed life story, Olaudah told of an instance when the crew had caught a plentiful amount of fish for themselves and when there was some left over, they threw it overboard rather than give it to any of the captives; driven by hunger, some slaves tried to get a small piece or two for themselves for which they were flogged.

Olaudah describes the bewildering scene when they arrived at Barbados and were divided into groups or "parcels" in the slave yard for the buyers to choose from, and the rush and clamor of the buyers. Often, sibling slaves were divided up into separate groups for sale, never to be reconnected again, which caused much despair for 
those family members who were separated. Olaudah was not sold in Barbados but taken on to Virginia to work at a plantation where there were no other Africans that he could communicate with, which left him grieving and miserable as he describes it. It was there that he saw for the first time a punishment tool on the slave cook, an iron muzzle, which held her jaw shut so that she could not eat or drink.

Olaudah spent five or six years working on merchant ships and military man-of-war vessels traveling to numerous countries under several different slave masters, during which time he was generally treated somewhat better than most slaves. One owner, $\mathrm{Mr}$. King from Philadelphia, was a merchant and had Olaudah working on several different vessels wherein he added to his set of useful skills. This master treated him with kindness, which was one of a few such moments in his life when things were not as dire. But during his slave tenure he witnessed many horrendous treatments of other Black (referenced in Olaudah's narrative as Negro) slaves. He notes, for example, that it was common for slaves on Caribbean islands to be branded with their master's initials and weighed down with heavy iron hooks and chains around their necks. Instruments of torture such as the iron muzzle and thumb screws were applied for seemingly minor actions. An almost routine practice was to violate female slaves and rob them of their chastity, even children less than ten years old. In Monserrat he saw a Negro staked to the ground, cut multiple times and portions of his ears removed because he had purportedly connected with a common white prostitute, the irony of that instance heavy given that white men frequently took liberties with indentured Negro women. Many of these atrocities, he says, 
drove slaves to seek death as a refuge from these intolerable acts.

\section{The Soleils Journey}

The slaves on the Soleils voyage did not experience the Middle Passage, but it was nonetheless a long journey from Port Mahe in the Seychelles to the southwest coast of Madagascar, roughly between 1,500 and 1,800 miles. After the Royal Navy arrested the ship, crew, and cargo of slaves, they were subsequently carried, or presumably towed, around the south point and up the east side of Madagascar, then northeast to the island of Mauritius, approximately another 1,500 miles, to reach the Vice Admiralty court of adjudication. Thus, the slaves endured at least 3,000 miles of ocean travel in cramped and despicable conditions, which would be essentially equivalent to experiencing the Middle Passage across the Atlantic, save for their stop-off at Madagascar. Although there are no details in the HCA 35/8 Record Book regarding the travel conditions, precise trip length, specifics of the Soleils dimensions, nor during which portion(s) of the journey the six slaves perished, it can be postulated based on experiences described by former slaves who were aboard transatlantic slaving vessels such as Olaudah Equiano that the slaves on board the Soleil assuredly suffered similar extreme challenges of painful discomfort, illness, humiliation, perhaps retribution or even near-death punishments, depression, malfeasance, and other horrors of ship-board incarceration.

Had the Soleil not been captured by the British and condemned before completing the planned voyage, and had the slaves not been turned over to the authorities in Port Louis, the 146 souls 
who survived the journey to Mauritius would likely have been subjected to the non-stop Atlantic crossing, and those that survive would have disembarked at the planned slaving port destination such as Bahia, Brazil, or even further north to the West Indies or beyond. They would have then begun lives of servitude under treatment as less than human chattel, under varying degrees of oppression, most land-bound on plantations producing sugar, cotton and other staples, while others such as Olaudah may have been sold to maritime masters. The slaves would not have been reunited with any kin or kith from their home states in Africa while they remained unfree slaves and thus would have had to create new networks in their new settings. Further, once the Abolition of the Slave Trade Act became law in 1807, the enforcement of the law through slave ship seizures by the British government did not mean that emancipated slaves were then returned to their homelands; rather, they were set to work as "free" workers on plantations or other work sites where slaves were used usually in the immediate area or region near the British court where the condemnation proceedings occurred. The government did not want to return the slaves to the closest home ports or ports of embarkation for concern that they would be recaptured and enslaved. The slaves on board the Soleil most certainly would never again know the lives they had before their kidnappings nor the lives they would have had in their homelands; they learned the unimaginable degrees to which inhumanity existed. 


\section{Bibliography}

Emory University. "Trans-Atlantic Slave Trade Database." Accessed November 11, 2017 and December 4-6, 2017. http://www.slavevoyages.org.

Harms, Robert. The Diligent: A Voyage Through the Worlds of the Slave Trade. New York: Basic Books, A member of the Perseus Books Group, 2002.

The National Archives of the United Kingdom. Slave Trade Advisor to the Treasury: Report Books, HCA 35/8, 1821-1891.

University of North Carolina at Chapel Hill. "Documenting the American South, the North American Slave Narratives Database." Last modified December 4, 2017. Accessed December 5, 2017. http://docsouth.unc.edu/neh/chronautobio.html. 


\section{AUTHOR BIOGRAPHY AMANDA CASILLAS}

Amanda is a third-year transfer history student at Cal Poly. Her primary interest of study is United States, more specifically modern U.S. history. In her free time, Amanda sings in choir at Cal Poly and watches various movies and TV shows. After graduation, Amanda hopes to find work anywhere she can write. 


\section{The Uniao: Inhumanity and Complexities of the Transatlantic Slave Trade, 1820s}

\section{AMANDA CASILLAS}

On the summer day of July 14,1825 , the waves collapsed gracefully on the shores of Bahia, Brazil. The palm trees along the shore and the green and yellow colors of the Brazilian Flag swayed. The salty air began to enter the lungs of the 25 crewmen on board the Uniao as they were preparing to depart from Brazil. ${ }^{1}$ The Uniao was a Brazilian schooner that weighed about 118 tons. ${ }^{2}$ On the Uniao, a passport enlisted to the schooner stated that Vicente de Paulo de Silva was the owner of the vessel and the vessel had plans to travel to Molembo, Africa. ${ }^{3}$ However, the journey the Uniao took differed from the voyage listed on the passport. Instead of traveling to Molembo, the Uniao sailed to Lagos, Africa.

1 Report of the Case of the Uniao (17 June 1826), The National Archives of the UK (TNA), HCA 35/9, p. 101.

2 Report of the Case of the Brazilian Schooner, Irish University Press, IUP 11, 39.

3 Report of the Case of the Uniao (1826), (TNA), HCA 35/9, p. 101. 
On September 1, 1825, the Uniao arrived in Lagos and received, according to the vessel's Master Jose Ramos Gomis and the Mate Jose da Rosa, 364 captives. ${ }^{4}$ Once on board the Uniao, the captives were "crammed in such a way that they could scarcely breathe." 5 Then, the Uniao began to make the journey back to Brazil to deliver the captives.

The Uniao represents one of the 138 slave ships that left $\mathrm{Ba}$ hia and sailed to Lagos during the years of 1812 to $1851 .^{6}$ In addition, the Uniao was one of about 13 Brazilian slave ships that were captured and taken to Sierra Leone between the time Brazil gained its independence and the establishment of the British and Brazilian Court of Mixed Commission. ${ }^{7}$ While the story of the Uniao cannot be used to generalize the transatlantic slave trade as a whole, the story of the Uniao shows how broader trends of the slave trade applied to one specific slave ship. Many researchers have spent time researching the abolition of the transatlantic slave trade, but few researchers have studied how abolition impacted one specific slave ship. ${ }^{8}$ Investigating one specific slave ship can reveal an extensive amount of information about anti-slavery movements and the conditions of slave ships in the Atlantic. The case of the Uniao demonstrates the inhumane $4 \quad$ Ibid.

5 "Supply of Water," Caledonian Mercury (Edinburgh, Scotland), December $29,1825$.

6 Voyages Database. 2019. Voyages: The Trans-Atlantic Slave Trade Database. https://www.slavevoyages.org (accessed March 15, 2019).

$7 \quad$ Peter Grindal, Opposing the Slavers: The Royal Navy's Campaign Against the Atlantic Slave Trade (London: I.B. Tauris \& Co. Ltd, 2016), 707-771. 8 Exceptions include The Diligent by Robert Harms and The Voyage of the Slave Ship Hare: A Journey into Captivity from Sierra Leone to South Carolina by Sean M. Kelley. 
conditions of the transatlantic slave trade that allowed for diseases to spread and the complexities of British antislavery movements in Portugal and Brazil in the 1820s.

The Portuguese viewed slavery as a fundamental part of society in Brazil. Slavers were often praised in Brazil for purchasing captives from Africa to impress the king and to "[Save] the negroes' souls by buying their bodies." "When Brazil claimed independence, on September 7, 1822, from Portugal, Brazil had to establish themselves among other countries. Therefore, it made sense for Brazil to continue utilizing the slave trade to create a desirable economy. In Brazil, the dominant use of seaports was to deliver the captives from Africa that were collected by Brazilians. However, Bahia was one of the most prominent ports in Brazil for the slave trade and had strong commercial ties with the Bight of Benin due to Bahia's reliance on slave labor for plantations. As the British began to advocate for the abolition of the slave trade, the British began to pressure Brazil to diminish its reliance on the slave trade after Brazil gained its independence from Portugal. The pressure exasperated by the British caused Brazil to reshape their social order based on the notion that "a constantly maintained supply of African labour, [would make Brazil] unfitted for progress and for social integration." ${ }^{10}$ Subsequently, Brazil began to gradually work with Britain to abolish the slave trade. Until Brazil agreed to work with Britain to abolish the slave trade, Britain would capture Brazilian ships and condemn the vessels.

On September 9, 1825, the H.M.S. Atholl was sailing along 9 Pierre Verger, Bahia and the West African Trade, 1549-1851 (Nigeria: Ibadan University Press, 1964), 1.

$10 \quad$ Ibid, 31. 
the Atlantic Ocean when Captain James Arthur Murray noticed a schooner sailing under Brazilian colors north of Princes Island. ${ }^{11}$ Captain James Arthur Murray approached the vessel in the company of the H.M.S. Esk and the H.M.S. Redwing. ${ }^{12}$ According to a letter from the Captain of the Redwing, the Redwing chased the Uniao "into the mouths of his majesty's ships Atholl and Esk, and thus hemmed in on all sides." 13 Murray quickly detained the Brazilian schooner, the Uniao, and its master, Jose Ramos Gomis, based on the discovery of a total number of 361 captives on board at the time of capture. The Captain of the H.M.S. Redwing stated that the captives were "crammed in such a way that they could scarcely breathe." 14 The 361 captives on board at the time of capture consisted of 217 men, 30 women, 80 boys, and 33 girls. ${ }^{15}$ Murray detained the Uniao based on the fact that the Uniao was participating in the slave trade north of the equator. ${ }^{16}$ Once Murray detained the Brazilian schooner, Murray took the vessel to Sierra Leone to be tried by the British and Portuguese Court of Mixed Commission.

On the journey to Sierra Leone, the health of the captives depleted. A total of 112 captives died on the journey to Sierra Leone from the place of capture. Consequently, at the time of arrival, there were a total of 249 captives that consisted of 138 men, 25 women, 11 Chart of Vessels Condemned in 1825 at the British and Portuguese Mixed Commission (6 Feb. 1826), The National Archives of the UK (TNA), FO 84/48, p.100. The exact coordinates that were listed are 2.33 " N, 4.17" E.

12 Report of the Uniao (1826), (TNA), HCA 35/9, p. 100-102.

13 "Supply," Caledonian (Scotland), 1825.

14 "Supply," Caledonian (Scotland), 1825.

15 Report of the Uniao (1826), (TNA), HCA 35/9, 100.

16 George Rendall, Esq. to Mr. Secretary Canning (2 June 1826), Irish University Press, IUP 11, pg. 39. 
53 boys, and 33 girls. In the report of the case of the

Uniao, it states that many of these deaths were most likely due to multiple cases of smallpox and dysentery. ${ }^{17}$ There was no surgeon on board the H.M.S. Atholl to look after the health of the captives. Regardless, the report states "that the greatest care was taken of [the captives that were on board the Atholl]." 18 Once the vessel arrived in Sierra Leone on October 21, 1825, the surgeon attached to the British and Portuguese Court of Mixed Commissions visited the vessel and found a total of eleven remaining cases of smallpox and several cases of dysentery. ${ }^{19}$ Due to this discovery, the surgeon decided to put the Uniao on quarantine regulations. ${ }^{20}$ With all of the Uniaoss casualties, the mortality rate rose to 32 percent. A mortality rate of at least 32 percent was highly uncommon in the transatlantic slave trade. For instance, the Uniao was one of 588 slave ships that had a mortality rate of at least 32 percent. ${ }^{21}$

Unlike a mortality rate of at least 32 percent, it was common during the transatlantic slave trade for captives' health to deplete. While on the shores of Africa, ship captains would negotiate for the healthiest Africans. However, "the proliferation of dangerous maladies,... often weakened captives' valuable bodies." ${ }^{22}$ On board

17 Report of the Uniao (1826), (TNA), HCA 35/9, 100.

18 Ibid.

19 Ibid.

20 Ibid.

21 Voyages Database. 2019. Voyages: The Trans-Atlantic Slave Trade Database. https://www.slavevoyages.org (accessed March 15, 2019).

22 Sowande' Mustakeem “"II Never Have Such a Sickly Ship Before”: Diet, Disease, and Mortality in 18th-Century Atlantic Slaving Voyages" The Journal of African American History 93, no. 4 (Fall 2008): 475. 
slave ships, "sickness and disease... fostered by the incubation of contagious and often deadly illnesses circulated and spread in the bowels of slaving vessels." ${ }^{23}$ The Uniao allowed for diseases to fester by having all of the captives on board crammed below the deck, causing large outbreaks of dysentery and smallpox. According to Sowande' Mustakeem, causes of disease outbreaks were a combination of "violent and brutal treatment... [as well as] the limited amount of medical resources and lack of extensive medical knowledge on part of the ship captains and crew." ${ }^{24}$ The Uniao is an example of both brutal treatment and lack of medical resources. On board the Uniao, there was a lack of a surgeon or medical professional. In addition, the Uniao created a space for diseases to spread rapidly by cramming the enslaved Africans in a way that limited the amount of oxygen and fresh air. One of the diseases that spread on the Uniao was smallpox. Smallpox was a commonly spread disease during the transatlantic slave trade. Smallpox usually caused pustules to form over the entire body that would scab and harden until they were scaled off. ${ }^{25}$ While captives were infected with smallpox, other symptoms would arise. The possible symptoms of smallpox could include vomiting, drowsiness, extreme pain, and bleeding from the nose or mouth. ${ }^{26}$ During the transatlantic slave trade, medical professionals often suggested providing patients with cool air. ${ }^{27}$ Whether or not it impacted the severity of smallpox, the Uniao did not provide its captives with the

23 Ibid., 476.

24 Ibid., 479.

25 Ibid., 487.

26 Ibid., 487.

27 Ibid., 488. 
suggested cool air. In the same way that diseases were complex, the anti-slavery movements that were created to abolish the slave trade were also complex.

The slave trade was one of the fundamental parts of society by the 1800 s. However, by the year 1807 , Britain began to pass multiple laws to prohibit the slave trade within Britain. Britain's efforts to abolish the slave trade did not end with the abolition in their territories. Britain began to internationalize abolition and began to try to work with other countries to abolish the slave trade. In order to abolish the slave trade, the British began to develop treaties and create courts with the countries that participated in the slave trade. Nonetheless, many of the countries that Britain tried to work with were resistant to Britain $s$ efforts to abolish the slave trade. Portugal happened to be the most resistant to Britains' internationalization of abolition.

\section{The Congress of Vienna in 1815 marks the turning point of abolishing the slave trade.}

The Congress of Vienna allowed Britain to convince other countries in Europe to "ratify increasingly powerful treaties against the slave trade." 28 However, according to Seymour Drescher, "the other rulers' reactions ranged from deeply hostile to abolition mildly sympathetic, more or less in proportion to their distance from, and interest in, the Atlantic system. All were wary about giving the world's only super sea power more power at sea." ${ }^{29}$ At the time of the

28 Jenny S. Martinez "Antislavery Courts and the Dawn of International Human Rights Law" The Yale Law Journal 117, no. 4 (Jan. 2008): 554-555.

29 Seymour Drescher, Abolition: A History of Slavery and Antislavery (Cam- 
Congress of Vienna, Britain had substantial "military and economic power." ${ }^{30}$ Therefore, all of the other countries were willing to come to an agreement, but the other countries were not willing to do whatever Britain wanted. Out of all the other leaders, Portugal needed the most convincing. Conversely, at the end of the Congress of Vienna, Portugal agreed to work with Britain to gradually abolish the slave trade. Portugal's reason for agreeing was documented in the Case of the Fortuna.

"His Royal Highness the Prince Regent of Portugal, being fully convinced of the injustice... of the Slave Trade, and of the great disadvantages which arise from the necessity of introducing and continually renewing a foreign and factitious population for the purpose of labour and industry within his South American dominions, has resolved to co-operate with his Britannic Majesty, in the cause of humanity and justice, by adopting the most efficacious means for bringing about a gradual Abolition of the Slave Trade throughout the whole of his dominions." ${ }^{31}$

In other words, Portugal agreed that the slave trade was harming their colonies in South America more than the slave trade was benefitting them. In addition, Portugal decided to co-operate with Britain and gradually abolish the slave trade in any Portuguese owned lands. The treaties created at the Congress of Vienna led to the establishment of Courts of Mixed Commission.

bridge: Cambridge University Press, 2009), 230.

30 Martinez "Antislavery Courts and the Dawn..." The Yale Law Journal 117, no.4 (2008): 555.

31 Case of the Fortuna, Report of the Committee of the African Institution 5 (1811): 28 . 
After the ratification of the treaties created at the Congress of Vienna, Courts of Mixed Commission began to be established throughout the globe. The main objective of the Courts of Mixed Commission was to help abolish the slave trade. Britain established many different types of Mixed Commission Courts, and many of these courts were at various locations throughout the world. For example, "Under each of the treaties, one court was to be set up in a British possession, and another in a Spanish, Portuguese, or Dutch possession, respectively...courts were set up in Freetown, Sierra Leone; Havana, Cuba; Rio de Janeiro, Brazil; and Suriname." ${ }^{2}$ The specific court that heard the case of the Uniao was the British and Portuguese Court of Mixed Commission in Sierra Leone. In the British and Portuguese Court of Mixed Commission in Sierra Leone, a British judge and a Portuguese judge would hear cases of captured slave ships and declare sentences together, other Courts of Mixed Commission had similar processes. The Uniao was a Brazilian schooner captured after Brazil claimed its independence from Portugal. However, Britain did not have any treaty or a Court of Mixed Commission with Brazil in the year of 1825. A treaty between Brazil and Britain would not be signed until November 23, 1826, and a British and Brazilian Court of Mixed Commission would not be established until 1828. ${ }^{33}$ Therefore, the lack of a British and Brazilian Court of Mixed Commission caused confusion about what to do with cap-

32 Martinez "Antislavery Courts and the Dawn..." The Yale Law Journal 117, no.4 (2008): 579.

33 Leslie Bethell "The Mixed Commissions for the Suppression of the Transatlantic Slave Trade in the Nineteenth Century" The Journal of African History 70, no. 1 (1966): 82. 
tured Brazilian slave ships.

Once the Uniao arrived in Sierra Leone, it was put on trial by the British and Portuguese Court of Mixed Commission. At the trial, it was clear that the Uniao was guilty of participating in the slave trade. One of the ways the Uniao was found guilty was that the enslaved Africans on board were taken captive in Lagos. In 1815, it became illegal to participate in the slave trade north of the equator, and Lagos lies about 6 degrees north of the equator. ${ }^{34}$

According to the Convention between Britain and Portugal, signed at Vienna on January 21, 1815,

"it shall not be lawful for any of the subjects of the Crown of Portugal to purchase Slaves, or to carry on the Slave Trade, on any part of the Coast of Africa to the northward of the Equator, upon any pretext or in any manner whatsoever. Provided nevertheless, that the said provision shall not extend to any ship or ships having cleared out from the ports of Brazil previous to the publication of such ratification: and provided the voyage, in which such ship or ships are engaged, shall not be protracted beyond six months after such publication as aforesaid." 35

In other words, Portugal could only participate in the slave trade south of the equator, or at ports, Portugal had owned previously. However, the Uniao was not the only Brazilian slave ship to participate in the slave trade north of the equator. According to Pierre Verger, "In 1826, the British consul, Charles Stuart wrote to the Foreign Office that nine-tenths of the annual importation of 34 George Rendall, Esq., IUP 11, 39.

35 Convention concerning abolition of the slave trade, Britian-Portugal, January 22, 1815, Report of the Committee of the African Institution 9, 81 . 
18,000 slaves came from north of the Equator, in defiance of the existing treaties." ${ }^{36}$ The second way the Uniao was proven guilty was the number of tons the schooner had. The Uniao weighed about 118 tons. With that amount of tonnage, the vessel should not transport more than 295 captives at one time. ${ }^{37}$ According to Herbert S. Klein, the law about tonnage was a Portuguese law that was created in 1684 that stated "If the decked ship in which there are portholes through which the negreos can easily receive the necessary air, then capacity below deck should be 7 adults... for every two tons; not having said portholes, the capacity should only be 5 slaves per two tons below decks." ${ }^{38}$ On November 24, 1813, the law was changed to allow five captives per two tons below deck regardless if there were portholes or not. ${ }^{39}$ On the other hand, at the time of capture, the Uniao was carrying 361captives. It was clear that the Uniao was guilty of slave trade once the Master Jose Ramos Gomis and the mate Jose da Rosa provided the same evidence in their dispositions. Both Gomis and Rosa, stated that " 364 slaves were taken on board the Uniao, during the voyage, all of whom were shipped at the River Lagos." 40 With this evidence, the British and Portuguese Court of Mixed Commission decreed the Uniao's condemnation and the emancipation of all the captives on board on November 4, 1825. Conversely, there was confusion about the validity of the condemnation of the Uniao. The 36 Verger, Bahia and the West..., 32.

37 Report of the Case of the Brazilian Schooner, Irish University Press, IUP 11, 39.

38 Herbert S. Klein The Middle Passage: Comparative Studies in the Atlantic Slave Trade (Princeton, NJ: Princeton University Press, 1978), 29. See Footnote 7.

39 Ibid.

40 Report of the Case..., IUP 11, 40. 
court was unsure if the condemnation was valid, now that Brazil was an independent state. The British and Portuguese Court of Mixed Commission eventually decided that because "the owner of their vessel and cargo was clothed with a Portuguese National Character, then the condemnation was valid under treaties and the convention with Portugal." ${ }^{41}$ If it pleased the King to have the Uniao's condemnation invalid because of Brazil's independence, then the British and Portuguese Court of Mixed Commission would retract their decision to condemn the Uniao.

During the years of 1822 to 1826 , there were only 13 cases of Brazilian slave ships in Sierra Leone. These cases caused confusion for both the British and Portuguese judges. In these cases, it was unclear what to do with the slave ships. Due to the limited amount of these cases, the Uniao stands out as a unique case. The lack of clarity would lead Britain to create a treaty with Brazil in 1826 and establish a British and Brazilian Court of Mixed Commission in 1828. The treaty between the Portuguese and the British would be used as a guideline and added to the new treaty between the Brazilians and the British. ${ }^{42}$ Despite the lack of a Court of Mixed Commission, the treaty between Brazil and Britain at least gave the judges in Sierra Leone a clue as to what to do with the captured Brazilian slave ships.

In Sierra Leone, once a ship was condemned all of the goods on board the vessel were auctioned off. The Uniao was no exception. After the Uniaoss condemnation, the Court of Mixed Commission

41 Complete Report of the Case of the Uniao, The National Archives of the UK (TNA), HCA 35/9, 279.

42 Bethell "The Mixed Commissions for the Suppression..." The Journal of African History 70 (1966): 82. 
held an auction to sell all of the goods and merchandise. The auction accumulated a total of 214 pounds, 13 shillings, and 3 farthings. ${ }^{43}$ The British and Portuguese Court of Mixed Commission divided the money up between the British, the Portuguese, and the captain of the vessel that captured the slave ship. Captains of captor vessels received prize money for capturing a slave ship and transporting the ship to Sierra Leone. According to the document containing Captain Murray's earnings, Captain James Arthur Murray received a bounty of 3610 pounds. ${ }^{44}$ A bounty of 3610 pounds was considered the normal bounty for delivering 361 captives to Sierra Leone.

Following the Uniaoss condemnation, the captives that were on board the Uniao went through a process of liberation. Before the captives liberation, officials in Sierra Leone produced a registry of the captives that were on board the Uniao containing their names and descriptions. The register states that a total of 35 captives died before they had the opportunity to have their descriptions taken. The 35 captives that died before their description consisted of thirty men, four women, and one girl. ${ }^{45}$ In addition, the total cases of dysentery and smallpox increased to 150 cases. The register sheds light on the captives on board the Uniao. For example, the register shows that the captives were aged anywhere between fifty and eight. The register also provides a list of brands, such as AC, C, W, B, and an unclear mark that appears to be a mix of C and D, usually placed on either 43 Expense Report for the Uniao (10 Jan. 1826), The National Archives of the UK (TNA), FO 84/49, p.28.

44 Captain James Arthur Murray's Earnings, The National Archives of the UK (TNA), HCA 35/12, 184.

45 Register of Captives that were on board Uniao, The National Archives of the UK (TNA), HCA 35/9, 266-272. 
the right or left breast. ${ }^{46}$ Some of the men also had marks and tattoos on various locations on their bodies. The majority of the captives came from Yoruba. After the officials collected as much information as possible, the captives would go through a process of liberation

The surviving captives of the Uniao went through the process of liberation in Sierra Leone. However, liberation did not equal freedom. The British and Portuguese Court of Mixed Commission not only condemned the Uniao, the British and Portuguese Court of Mixed Commission also called for the emancipation of the enslaved Africans where the captives were meant to be "employed as servants or free laborers." 47 The register kept by the Liberated Africans Department in Sierra Leone maintained a list that described the placement of each captive after the process of emancipation. This register describes how seventy-one men were "placed in public works at Sierra Leone." 48 The register describes how many captives were sent to the hospital before the captives went to their assigned places of work. The number of captives who went to the hospital after the process of taking descriptions was around forty-three individuals. In the register, it reveals that once the captives in the hospital recovered, the captives went to various locations. Unfortunately, some of these locations are hard to read. The number of those infected with diseases increased and more captives had passed away to Wilberforce after the captives went through the process of getting descriptions taken.

$46 \quad$ Ibid.

47 Report of the Case of the Uniao, The National Archives of the UK (TNA), HCA 35/9, 264.

48 Register of 214 people that were on board the Uniao (4 Nov. 1825), Sierra Leone Public Archives, SLR20322-20570, 26. 
Fifty-five more captives passed away from the diseases that spread throughout the Uniaoss captive population. The fifty-five captives that passed away consisted of forty men, eight boys, five women, and two girls. In addition to the number of captives sent to the hospital and the number of captives that passed away, this register also provides the names of people who "employed» the captives. ${ }^{49}$ For example, John Forsyth had two boys sent to him and Sarah Harding had one girl sent to her. Nevertheless, on this register, it is not hard to notice that only the boys and girls were assigned to specific individuals, but the men and the women were assigned to various locations. This register helps provide information on the process of liberation many enslaved Africans experienced in Sierra Leone.

The liberation of the enslaved Africans did not necessarily provide the captives' with the freedom the word liberation alludes to. According to Daniel Domingues Da Silva,

"Some [liberated Africans] faced conditions that differed little from enslaved people living around the world. At the other extreme might be the large numbers of [captives] had left their slave ships to return to their home countries, or... emerged as major merchants in Freetown, or who led broadly self-sufficient existences on smallholdings in the Freetown hinterland." 50

Once a captive went through the process of liberation, they either had to enlist in the army or they were forced to complete about

Ibid.

50 Daniel Domingues Da Silva "The Diaspora of Africans Liberated from Slave Ships in the Nineteenth Century" Journal of African History 55 no. 3, (2014): 348. 
fourteen years of an apprenticeship. ${ }^{51}$ However, liberated Africans were sent to various villages "regardless of age and with no attempt to restrict their activities," and within these villages, the liberated Africans "received no government support." ${ }^{2}$ Liberated Africans were either forced into some form of servitude or left to fend for themselves in unknown lands with no support. Therefore, the word liberation in the context of the transatlantic slave trade does not comply with the word's definition.

The case of the Uniao was unique. It was one of the 588 slave ships with a mortality rate of 32 percent or higher. The Uniao was also one of the Brazilian ships captured between Brazil's independence and the establishment of the British and Brazilian Court of Mixed Commission in Sierra Leone. While the case of the Uniao cannot be used to generalize the transatlantic slave trade, the Uniao exemplifies the inhumane conditions of the transatlantic slave trade that allowed for diseases to spread and the complexities of British antislavery movements in Portugal and Brazil of the 1820s.

51 Da Silva "The Diaspora of Africans Liberated from Slave Ships" Journal of African History 55, (2014): 355.

52 Da Silva "The Diaspora of Africans Liberated from Slave Ships" Journal of African History 55, (2014): 360. 
Amanda Casillas 


\section{Bibliography}

\section{Primary Sources:}

Britain. Case of the Fortuna, Report of the Committee of the African Institution 5 (1811): 28.

Britain. Convention concerning abolition of the slave trade with Britain and Portugal, January 22, 1815, Report of the Committee of the African Institution 9.

Captain James Arthur Murray's Earnings, The National Archives of the UK (TNA), HCA 35/12, 184.

Chart of Vessels Condemned in 1825 at the British and Portuguese Mixed Commission (6 Feb. 1826), The National Archives of the UK (TNA), FO 84/48, p.100.

Expense Report for the Uniao (10 Jan. 1826), The National Archives of the UK (TNA), FO 84/49, p.28.

George Rendall, Esq. to Mr. Secretary Canning (2 June 1826), Irish University Press, IUP 11, pg. 39.

Register of Captives that were on board Uniao, The National Archives of the UK (TNA), HCA 35/9, 266-272.

Register of 214 people that were on board the Uniao (4 Nov. 
1825), Sierra Leone Public Archives, SLR20322-20570, 26.

Report of the Case of the Brazilian Schooner, Irish University Press, IUP 11, 39.

Report of the Case of the Uniao (17 June 1826), The National Archives of the UK (TNA), HCA 35/9, pp. 101-102.

"Supply of Water," Caledonian Mercury (Edinburgh, Scotland), December 29, 1825.

\section{Secondary Sources:}

Bethell, Leslie. "The Mixed Commissions for the Suppression of the Transatlantic Slave Trade in the Nineteenth Century" Journal of African History 6, no.1. (1966): 79-93.

Domingues da Silva, Daniel et al. "The Diaspora of Africans Liberated From Slave Ships in the Nineteenth Century" Journal of African History 55, no.1 (2014) 347-369.

Drescher, Seymour. Abolition: A History of Slavery and Antislavery (New York: Cambridge University Press, 2009).

Grindal, Peter. Opposing the Slavers: The Royal Navy's Campaign against the Atlantic Slave Trade (London: I.B. Taurus, 2016). 
Klein, Herbert S., The Middle Passage: Comparative Studies in the Atlantic Slave Trade (Princeton, NJ: Princeton University Press, 1978).

Martinez, Jenny S. "Antislavery Courts and the Dawn of International Human Rights" The Yale Law Journal 117, no.4. (2008): 550-641.

Mustakeem, Sowande. "I Never Have Such a Sickly Ship Before: Diet, Disease, and Mortality in 18th-Century Atlantic Slaving Voyages" The Journal of African American History 93, no. 4 (Fall 2008): 474-476.

Verger, Pierre. Bahia and the West African Trade, 1549-1851. (Institute of African Studies by Ibadan University Press, 1964).

\section{Digital Sources:}

Etlis, David, David Richardson, Manolo Florentino and Stephen D. Behrendt. 2019. Voyages: The Transatlantic Slave Trade Database. Online Database. www. slavevoyages.org/. Accessed, 2019. 
Etlis, David, David Richardson, Manolo Florentino and Stephen D. Behrendt. 2019. African Names Database. Online Database. www. slavevoyages.org/. Accessed, 2019 


\section{AUTHOR BIOGRAPHY EMILY TAKETA}

Emily is a first-year History major from Roseville, California. Her research interests include presidential history, 1960s America, and comparative politics. Outside of academics, Emily enjoys the beach and is involved in Open House Committee and SLO Days Summer Crew. 


\section{Foundational Dissent: The 1965 Quota Controversy}

\section{EMILY TAKETA}

Over its history, Cal Poly has fiercely adhered to and subsequently strayed away from its commitment to technical education and professional disciplines. What began as a school with very limited fields of study expanded into a college of technically focused coursework and is now a comprehensive polytechnic university that has implemented and expanded academic and liberal subjects. ${ }^{1}$ This transition did not come easily, and it was not often welcome by the school administration. President Julian A. McPhee (1933-1966) especially struggled against the growth of the liberal arts departments in a crusade fueled by his loyalty to the polytechnic doctrine of the college. ${ }^{2}$ But students pushed back at his efforts, demanding more attention for the school's liberal arts programs.

$1 \quad$ Nancy E. Loe and Dan Howard-Greene, Cal Poly: First Hundred Years (San Luis Obispo, CA: Robert E. Kennedy Library, California Polytechnic State University, 2001) 84 .

2 Ibid. 
This paper argues that student backlash to President McPhee's 1965 "Emphasis for Tomorrow" enrollment policy demonstrated the student body's resistance to Cal Poly's polytechnic foundation and its desire for a more robust liberal arts program.

In 1901, the California legislature passed a bill to establish the California Polytechnic School for the purpose of training students in the "practical application of knowledge," a focus maintained by school officials throughout Cal Poly's early decades. ${ }^{3}$ When President McPhee took office in 1933, he planned on preparing Cal Poly's students for careers in industry and agriculture, carrying on the distinct educational legacy of the school. ${ }^{4}$ In 1960, the California legislature passed the Donahoe Higher Education Act. This bill placed specific emphasis on applied learning and teacher education in the California State University system; this concerned McPhee because it forced him to implement a more complete liberal arts program. ${ }^{5}$ Apprehensive about this "Master Plan," McPhee believed a liberal arts curriculum would "creat $[\mathrm{e}]$ an imbalance" that would contrast Cal Poly's learn-by-doing origins. ${ }^{6}$ Up until this time, the liberal arts curriculum functioned more as a supplement to the other majors rather than its own complete and exhaustive program. In 1965, President McPhee made his most discernible attempt to halt the liberal arts at Cal Poly. He created a policy entitled "Emphasis for Tomorrow,"

3 Nancy E. Loe and Dan Howard-Greene, Cal Poly: First Hundred Years (San Luis Obispo, CA: Robert E. Kennedy Library, California Polytechnic State University, 2001) 15.

4 Ibid., 41.

5 Ibid., 84.

6 Julian A. McPhee to Senator Vernon Sturgeon. March 20, 1965. California State Polytechnic College, San Luis Obispo, CA. 
which placed an enrollment quota on the English, Education, and Social-Science departments. ${ }^{7}$ Despite these three departments only occupying $13 \%$ of the school's enrollment, it was President McPhee's belief that those departments were "developing too rapidly" and that Cal Poly's technical origins should dictate its curriculum. ${ }^{8}$

Possibly to the surprise of President McPhee, the student body did not widely accept his new enrollment policy. In the book Cal Poly: The First Hundred Years, President McPhee's strife with liberal arts is discussed at length by authors Nancy E. Loe and Dan Howard Greene, but there is no mention of how students responded. This lack of mention suggests that the general student response to the enrollment policy was minor and insignificant. On the contrary, it was the controversial center of attention for nearly six months after the initial policy announcement. The student-run newspaper, $E l$ Mustang, communicated the student response. Within weeks of the policy announcement, irate Cal Poly students slammed the policy as "arbitrary and prejudicial" in a letter to the editor." They went on to list the negative effects that the enrollment limits would create, including the loss of faculty, higher per-student fees, and a decrease

7 Julian A. McPhee. Emphasis For Tomorrow: A Long Range Educational Plan. January, 1965. Box 144.01, Folder 2. Special Collections and Archives, California Polytechnic State University, San Luis Obispo, CA.

8 Memorandum from Julian A. McPhee to Senator Vernon Sturgeon. March 20, 1965. Box 23, Folder 24. Julian McPhee. Special Collections and Archives, California Polytechnic State University, San Luis Obispo, CA. $9 \quad$ James R. Silliman, John D. Mitchell, Robert J. Wilson, Alfred C. Granados, Michael H. Hayes. "Mailbag." El Mustang 27, no. 21 (January 15, 1965): 2, accessed November 14, 2018, https://digitalcommons.calpoly.edu/cgi/ viewcontent.cgi?article $=2190 \&$ context $=$ studentnewspaper. 
in the "well-roundedness" of other majors. ${ }^{10}$ Such a quick reaction from the students came largely as a surprise because the defense of liberal arts was not a usual occurrence for the decade, especially at a polytechnic school. The students also made note of how President McPhee was wrong to believe that a shift towards liberal arts caused the growth in these departments. This growth was "illusory" and only due to a structural change in the Education major. ${ }^{11}$ The students' argument was well-constructed and calculated, displaying how passionately they felt about beating the unpopular policy.

Not long after that letter to the editor was published, El Mustang published another article that spoke of how the Student Affairs Council passed a "resolution urging the administration" to eliminate the enrollment quotas as its pending implementation would result in a "reduction of academic standards" in each of the affected departments. ${ }^{12}$ This resolution had the backing of the majority of the student body and was resoundingly passed, then sent to the McPhee Administration. It must be noted that even though the liberal arts departments only accounted for a small percentage of the school, a greater portion of the school reacted and mobilized in their defense.

The authors of both the letter to the editor and the Student Affairs Council resolution fiercely advocated against President McPhee's policy, demonstrating the value they saw in the liberal arts programs. This intrinsic value of the liberal arts stood in contrast

12 Robert Boyd. "SAC OK’s Student Resolution." El Mustang 27, no. 17 (January 29, 1965): 1, accessed November 14, 2018, https://digitalcommons. calpoly.edu/cgi/viewcontent.cgi ?article=2194\&context=studentnewspaper. 
to President McPhee's steadfast vision of an exclusively career and industry centered university. The students placed worth where worth had not been placed before. This shift away from Cal Poly's origins is demonstrated by the persuasive empirical points of the students' letter to the editor and by the Student Affairs Council's resolution. These students believed that a college-level education was meant to encompass more than a singular professional skill, that it was meant to also grasp academic and intellectual disciplines as to holistically enrich the minds of students. With this in mind, the students contradicted what President McPhee had fought to preserve.

On account of this observation, Cal Poly: The First Hundred Years correctly suggests that President McPhee did all that was in his power to keep Cal Poly strictly polytechnic. He attempted to de-emphasize the departments that did not fit within his vision for the college. Cal Poly: The First Hundred Years fails to mention the student pushback against the policy, implying that the policy went without conflict. That fallacy buries the students who stood up for liberal arts at a time when those subjects were not valued by higher administration officials. By resisting this single enrollment policy, these students showed the first signs of contending with Cal Poly's deep-rooted polytechnic nature. These students created a shift in the dynamic of how Cal Poly was to be identified. What had been founded as a uniquely technical school finally began the slow transition towards expansion into academic and intellectual fields of study. McPhee's efforts to keep Cal Poly on a strictly polytechnic track fell through to the growth of a comprehensive set of liberal arts curriculum. 


\section{Bibliography}

Boyd, Robert. "SAC OK's Student Resolution." El Mustang 27, no. 21 (January 29, 1965): 1. Accessed November 14, 2018. https://digitalcommons.calpoly.edu/cgi/viewcontent.cgi?article $=2194 \&$ context $=$ studentnewspaper

Loe, Nancy E. and Dan Howard-Greene. Cal Poly: First Hundred Years. San Luis Obispo, CA: Robert E. Kennedy Library, 2001.

Julian A. McPhee to Senator Vernon Sturgeon. 20 March 1965. Box 23 Folder 24, 144.02 Julian McPhee. Special Collections and Archives, California Polytechnic State University.

McPhee, Julian A. Emphasis For Tomorrow: A Long Range Educational Plan. 144.01, Folder 2 Special Reports. Special Collections and Archives, California Polytechnic State University, 1965.

Silliman, James R., John D. Mitchell, Robert J. Wilson, Alfred C. Granados, Michael H. Hees. El Mustang 27, no. 17. (January 15. 1965): 2. Accessed November 14, 2018. https://digitalcommons.calpoly.edu/cgi/viewcontent. cgi?article $=2190 \&$ context $=$ studentnewspaper 


\section{AUTHOR BIOGRAPHY HUNTER WHITE}

Hunter White is a recently graduated History Major. He wastes most of his time thinking up author bios and balancing his ardent faith in community and his deep-seated terror of other people. 


\section{A War of Rebellion: Radical Politics in the Spanish Civil War HUNTER WHITE}

The Spanish Civil War was one of the seminal events of the twentieth century. It occurred in the interim of the two most destructive conflicts in human history and contained adherents to every radical ideology at the turn of the century. This has made it a useful lens into the study of the revolutionary movements of the period, but to focus on the war solely as a sort of laboratory for radical politics or a prophetic text for WWII is to lose sight of its distinctly Spanish roots and the effect of the Spanish character both on the war itself and the ideologies torrenting within it. The anarchist movement in Spain, the only European nation where it managed to gain actionable political power and territory, provides a window into the uniquely Spanish nature of the war. In fact, Spanish Anarchy was less about the adoption and implementation of a foreign politi- 
cal ideology, such as Vladimir Lenin's revolutionary Marxism or Mikhail Bakunin's social anarchy, and more an inherently Spanish event. Its consistent inability to achieve coherent political goals once it had taken power instead suggests that it was a specific Spanish outlet for some essential human passion. In The Rebel, Albert Camus argues that the individual desire to rebel is fundamental to the human character. This philosophy of personal rebellion better explains Spanish anarchism than Bakunin's thought. The anarchist movement, and other radical polemics, of the Spanish Civil War are closer in resemblance to Camus's rebellious philosophy than the revolutionary ones of Bakunin or Marx.

\section{The Rebel}

In The Rebel, Camus sought to unpack the centuries of revolution that had marked the period since the Enlightenment and its rejection of the divine right of kings. He found value in the natural inclination of the slave to rebel, to affirm that there is something in him which will not bow to every injustice, some inherent value worth protecting, something more precious than the mere continuance of his life. ${ }^{1}$ It takes no great leap to see the way in which this reasoning would conform with revolutionary proletarian philosophies such as Communism and Anarchism. When the rebel accepts his own life as collateral in the struggle for this greater goal, he is elevated from an individual struggle into a broader human one. A single rebellion must be a rebellion on behalf of all mankind or it loses its source: its inherent humanity. ${ }^{2}$ But Camus broke from these philosophies when

1 Albert Camus, The Rebel, Penguin Books, 2013, 1, 21-23.

2 Ibid., 12, 19. 
he differentiated between the natural human inclination for rebellion and the dialectical Marxist revolutions, wherein man becomes subject to a greater history, and any sin committed against the individual is absolved in this prophetic future. Using his logic of rebellion Camus denied the right to tyranny in service of history. When the revolution puts history before the individual, he relinquishes his status as rebel and becomes master. ${ }^{3}$

This particular view of revolutionary politics defined the anarchism of the Second Spanish Republic. It was a rebellious spirit stemming less from ideology or grand plans for a historical dialectic and more from a boiling rage at a history of injustices which had stewed for centuries. This natural human response to exploitation led not to a singular political revolution but to countless warring ideologies vying for power. In many ways, the Spanish Civil War was not a two-sided civil war but a series of various competing rebellions. As would be expected of a peasant and worker rebellion, its roots and causes can be found in Spain's centuries-old problems.

\section{Spain before the War}

Most Spanish political movements have had a distinctly grass roots character. They have been, for the most part, the work of the peasantry and the common man who have risen up and rebelled. During the Reconquista, small barbarian kingdoms began the work of driving out the Moors and uniting under a new Christian identity. After Napoleon drove out the king and placed his brother on the throne, autonomous guerrilla bands of common men and women 
made the country too odious to rule. ${ }^{4}$ It was always the lower classes of Spain who acted as keepers of a fiery Iberian independence. Even conservative politicians such as Antonio Canovas, restorer of the monarchy, commented upon the indispensable nature of the Spanish peasant in the preservation of Spain. ${ }^{5}$ This culture of grass root revolution and a history of political power needing to be rescued by the people provided the Spanish peasant with a unique and potent relationship between himself and those who governed him.

In the pre-industrial period, the church was the constant supporter and refuge for these revolutionary movements. Spain's strong Catholic faith provided an ideological basis as well as shelter and organization. Spain's lower classes could always rely on the Church as a way to influence politics and vice-versa. As Enlightenment ideas spread throughout Europe, the strength of the Church began to weaken, and its fear of liberal movements grew; it turned increasingly towards conservative politics and grew increasingly indebted and entwined with the landowning classes. ${ }^{6}$ This betrayal shattered working class faith and turned the clergy from a source of hope to a constant reminder of their oppression on heaven and earth. Once the Church had abandoned its traditional role as both a defender of the lowly and a bridge across classes, the peasantry was left with its historical potency and its growing anger without any means to assuage it. By now they were an army awaiting an ideology.

In this moment of need just such radical godless philosophies

$4 \quad$ Gerald Brenan, The Spanish Labyrinth an Account of the Social and Political Background of the Civil War, Univ. Press, 1967, 19-20, 312-313.

$5 \quad$ Ibid., 318.

6 Ibid., xxv. 
were spreading throughout Europe. Spain would have representatives from each, including devout Stalinists, more-moderate socialist unions (UGT), who focused on worker's rights as opposed to outright class struggle before the war, and anarchist unions(CNT), who believed in the complete eradication of the state and the abolition of private property. These competing factions would all play crucial roles in the Second Republic along with the bourgeois liberal republicans, but it is the unique success of the anarchist movement in Spain that provides the greatest insight into the radical movement and its fundamental roots.

Anarchism, as defined by Mikhail Bakunin, is a political philosophy based foremost upon what must be destroyed as opposed to what should be built. Bakunin spent much of his writing arguing against the legitimacy of any State which requires coercion. He argued instead for willful agreements between localized autonomous collectives. ${ }^{7}$ Both ideas spoke profoundly to a Spanish populace which had been enduring an incompetent centralizing government that, more often than not, enforced its will at the end of a rifle. ${ }^{8}$ It also spoke to the inherent independence of the various Spanish provinces, all of which believed they had the right to govern themselves better than the central government. It was for this reason that Anarchism took most readily in Catalan, with its centuries of separatism, and Andalucía, where for centuries peasants had been revolting, abolishing currency, and collectivizing land in a medieval tradition. ${ }^{9}$

7 Mikhail Bakunin, God and the State, Mother Earth Pub, 6-13.

8 Gerald Brenan, The Spanish Labyrinth an Account of the Social and Political Background of the Civil War, Univ. Pr, 1967, 115.

Ibid., 314-316. 
But what most thoroughly guides the Anarchist philosophy is rage. It is rebellion against society and is more concerned with declaring it unjust and worthy of destruction than getting lost in the weeds of governance. It is Camus's slave grabbing the hand of his master and declaring enough is enough whether or not God or history would be there to redeem him afterwards.

\section{International Aide}

The Spanish Civil War is perhaps the most international civil war in history. It boasted three different foreign powers providing direct intervention and assistance as well as countless volunteers from various nations. This foreign involvement proved crucial in the outcome of the war. Nearly every major battle was decided by the extent to which each side could acquire foreign aid, a competition which the Nationalist rebels won handily. ${ }^{10}$ It is thus important to examine foreign involvement and its ideological underpinnings.

Combatants from every major western Allied and Axis power would find their way into the conflict, but only the revolutionary states provided any official aid. The western democracies adhered to the Non-Intervention Agreement, wherein the European powers of the time and the United States agreed to avoid involvement in the war, including the selling of arms. Tired of the past and fearful for the future, they hoped to contain the conflict to Spain. Mussolini's Italy and Nazi Germany completely and immediately broke the agreement, with Stalin soon following in response. ${ }^{11}$ Though hated

10 Gabriel Jackson, A Concise History of the Spanish Civil War, Thames and Hudson, 1974, 12-17

11 Anthony Beevor, The Spanish Civil War, Peter Bedrick Books, 1983, 
enemies, the German and Italian fascists and the Russian Bolsheviks both viewed themselves as freeing their peoples from an oppressive liberal world order. The liberal democracies, on the other-hand, allowed a democratically elected European government to face a military coup and slip into fascism due to fear of their radical elements. When the nations of the world looked to Spain, they did not see competing factions or a regional civil war; they saw a nest of revolutionary fire. Those nations, still attached to their conservative liberal-institutions, wanted no part of such rebellion.

But it was just that rebellion which enticed multitudes of independent citizens to volunteer and fight for a nation which was not their own. Of the 4,000 Americans who served in the volunteer Lincoln Brigade, 100 were black men serving in the first integrated unit in American history, one which would be led by a black officer, Oliver Law, the first African-American to lead a mixed-race battalion, much less a predominately white one. These men were mostly communists and black nationalists disillusioned with the false freedom of American society. They saw the fight in Spain as one for the emancipation of man. It was not a fight contingent solely on political ideals either, as they wished to intervene in the Second Italo-Ethiopian war, defending a heretical monarchy, the year before. It was one based upon self-determination and the inherent dignity of man. ${ }^{12}$ It was an act of rebellion against a world which so often refused to acknowledge their humanity. Similar views on the conflict were shared by the white veterans of the Lincoln Brigade who would go on to be $14-22$.

12 Robin D. G. Kelley, “This Ain’t Ethiopia But It'll Do," African Americans In the Spanish Civil War, ed. Danny Duncan Collum, 5-43. 
blacklisted as "premature anti-fascists" during the period of McCarthyism. ${ }^{13}$ All these volunteers saw in Spain a great hope which they could not find in their own countries. They, like Camus's slave, no longer identified with nation or creed but with a broader humanity worth the sacrifice of their own small life.

\section{Crisis and Collapse}

Spain at the turn of the century was in crisis. It possessed a bloated and incompetent bureaucracy, a similarly expensive and incompetent army, and a monarchy with a habit of escaping to France at the first sign of trouble. The Spanish political system had no separation of powers: courts were controlled by the government, the cortes were elected through buying ballots or often just ignoring them, and political positions were bestowed through nepotism. In the last free election before the dictatorship of Primo de Rivera, 113 deputies were close relatives of political leaders. ${ }^{14}$ This Cosa Nostra system led to corruption so severe that in $1902,50 \%$ to $80 \%$ of property taxes went unpaid. This gross corruption of the tax system benefited the large landowner over the small one who often paid 30 to 40 pesetas per acre while the large estates paid next to nothing. ${ }^{15}$

The same top down corruption could be found in the military with its own bloated officer corps. During the Moroccan War in 1923 , there were 25,000 officers to 200,000 enlisted men.

13 John Gerassi, The Premature Antifascists: North American Volunteer in the Spanish Civil War 1936-39: an Oral History, Praeger, 1986, 45.

14 Gerald Brenan, The Spanish Labyrinth an Account of the Social and Political Background of the Civil War, Univ. Press, 1967, 33.

15 Ibid., 12-15. 
The military comprised over half of the Spanish budget in 1922 and despite this was grossly anachronistic, possessing obsolete artillery and entirely lacking airplanes or tanks; most of its budget went to officer pay instead of modern armaments. This old bloated force was greatly unpopular with the common people whose sons were sent to die by the droves in pointless and failed colonial wars. It had also gained a taste for declaring the government in need of saving in the form of its pronunciamentos, a coup by any other name. ${ }^{16}$ These factors made the military an unpopular institution even before the Civil War.

Between the central government, the military, and the church, it is difficult to find a single Spanish institution that was not an object of ire for the common Spaniard. In the face of such unpopular rule, the government and landowners responded with harsh reprisals. Strikes were violently disbanded. Anarchist leaders would be arrested without evidence and then shot in the back for supposedly attempting escape. ${ }^{17}$ Liberal reforms did not rid the government of such atrocities. In 1934, a sergeant was found innocent by a military tribunal in Burgos for the shooting of unarmed protesters which resulted in the death of eleven and the wounding of thirty more. Moments such as this drove many anarchists, including the CNT to proclaim that social democracies were even fouler than monarchical rule. ${ }^{18}$ The populace's rage would boil over countless times both in the streets and directly against the government, which had three Ibid., 91-94.

17 Ibid., 114.

18 Julian Casanova, Anarchism, the Republic and Civil War in Spain: 19311939, Taylor \& Francis, 2014, 26-31. 
Prime Ministers assassinated over a twenty-year span. ${ }^{19}$ It was for these reasons that Manuel Azana, President of the Second Republic, had made order his primary objective and continued many repressive policies that, unintentionally or not, supported the land-owning classes to the continued fury of union organizers. ${ }^{20}$

The anger and mobilization of the under classes was not then strictly political, as the achievement of their political agendas rarely brought about an end to their actions. Even with a legitimate and representative government, in the process of labor and agrarian reforms, violence continued. It was not a revolution based upon pure political aims; it was a violent rebellion against an entire society which had become unjust and abusive, and it would not be peacefully resolved without the individual Spaniard's dignity restored. It was a moral movement before a political one.

This can be seen especially during the Civil War itself by the ways in which the radical movements attempted and failed to govern. At the outbreak of the war, the CNT would see a huge leap in its functional political power. In the summer of 1936 Catalonia would become, perhaps, the first anarchist community since man left the wilderness. They gained power the same way the anarchists had gained any of their progress: in the streets. Though fantasies of common men, women, and children manning makeshift barricades are more apocryphal than factual, it was the anarchist militias that provided the major defense of Barcelona and as such found them-

19 Gerald Brenan, The Spanish Labyrinth an Account of the Social and Political Background of the Civil War, Univ. Press, 1967, 115.

20 Julian Casanova, Anarchism, the Republic and Civil War in Spain: 19311939, Taylor \& Francis, 2014, 7-9. 
selves at the levers of local power. The looming threat of fascism had tempered their puritanism, and a radical restructuring of society was not yet in the cards. ${ }^{21}$

Unlike the nationalist rebels, the anarchists could not rely on foreign aid from any western powers. ${ }^{22}$ Production could not cease, and the conditions were now worse than under the previous regime. Many of the reforms that had been earned by their collective action now had to be suspended in order to keep the war economy competitive with the combined efforts of the Fascist machine. This, combined with rising inflation, made life for the proletariat in the proletarian paradise all the worse, and now the entire workforce had learned the effectiveness of sabotaging production through late arrival, slow labor, theft, and other forms of worker's protest. ${ }^{23}$ It was now the anarchists who had to handle their own militant workers and their strikes. Even in Catalan, where the urban anarchist dream came as close to being realized as anywhere outside the Gates of Eden, its own proponents rebelled against it when they felt it to have degraded them.

Faced with difficulty in governing, the anarchists focused more on the destruction of the symbols of the old order than political organization. Churches were ransacked and turned to barracks, cafes, and dancehalls; icons were burned in mass bonfires, and priests

21 Julian Casanova, Anarchism, the Republic and Civil War in Spain: 19311939, Taylor \& Francis, 2014, 101-107.

22 Allen Guttmann, The Wound in the Heart: America and the Spanish Civil War, The Free Press of Glencoe, 1962, 21.

23 Julian Casanova, Anarchism, the Republic and Civil War in Spain: 19311939, Taylor \& Francis, 2014, 140. 
were forbidden from wearing the marks of their office. ${ }^{24}$ It was once again this base level anger, not politics, that spurned action. It was that same indomitable will to independence and dignity which most ingratiated Spain to anarchism which proved to be its greatest weakness once power was attained. The urge to destroy and liberate can only take one so far before the need to construct and organize arises. When this must be done with enemies on all sides, from an international Fascist conspiracy to Stalinists fearing a non-Soviet model of revolution to western nations abandoning a democracy in favor of a fascist dictatorship, it becomes nearly impossible.

This inability to sustain their boldest achievements can be seen again and again. At the start of the war, revolutionary posters were emblazoned with jack-booted women marching to freedom, rifles on shoulders, but in less than a year the rhetoric had returned to the standard patriarchal call of valiant motherhood, and women had all but vanished from the militias. ${ }^{25}$ Old Spanish feelings outlasted revolutionary fervor. Even without women, these anarchist militias proved difficult to maintain. One by one they found themselves absorbed into the regular army. The egalitarian Durruti Column became just another division in the Republican Army after the death of anarchist folk hero Buenaventura Durruti. They assimilated politically as well, joining the central government with five members on Caballero's Council of Defense. ${ }^{26}$ They had hoped to gain some

24 Gerald Brenan, The Spanish Labyrinth an Account of the Social and Political Background of the Civil War, Univ. Press, 1967, 246.

25 Julian Casanova, Anarchism, the Republic and Civil War in Spain: 19311939, Taylor \& Francis, 2014,140. 109-111.

26 Ibid., 114-118. 
modicum of influence upon the central government as they had managed in their activist striking days, but this too proved detrimental. The CNT's willingness to deal with the government splintered their support and led to several prominent leaders breaking off and starting splinter groups, the very plot of the conservative members of the Republican government. ${ }^{27}$ Without its radical polemic, in the eyes of the Spanish peasant, it was just another political party vying for power in a corrupted government.

This inability to rule proved disastrous in Andalucía when the anarchists attempted to solve Spain's great agrarian question which had plagued Spanish rulers since the Conde-Duque. Here they enacted Bakunin's ideas for the collectivization of rural land and social-and-gender equality. But in doing so they butted heads with centuries of cultural norms. The autonomy and independent nature of the Spanish people turned against them yet again. Andalusian peasants rebelled against both over-collectivization of land and the liberation of women. The communists seized this opportunity to drive a further wedge into their faction. ${ }^{28}$ In one final overture for assistance, the Spanish anarchists sought aide from the International Association of Workers, by this time made up mostly of anarchists and Trotskyists. There, the only active anarchist movement on the planet was dressed down by foreign intellectuals for collaboration with the other anti-fascist movements and impure ideology. By the end of the conference the Spanish delegation returned to its trenches aidless and the other delegates returned to their downy beds, heads held

28 Ibid., 133-36. 
high for their purity of thought. ${ }^{29}$ They were too radical in the field and not radical enough in the lecture hall. Spanish anarchism was never a purely ideological movement. No matter the source of the ideas or the slogans, the movement was distinctly Spanish, rooted in Spanish traditions, Spanish culture, and Spanish history. Its proponents in the field were interested in destroying the chains which had enslaved them, and anarchism promised the largest fire.

\section{Conclusion}

For the illiterate peasants and workers who made up the vast majority of the radical militias, it was never a question of fulfilling any ideology; it was instead the release of centuries of pent up anger. Anarchism was not a prescription for their problems but a tool for the destruction of the state which had so unjustly ruled them. It was not Marx's end of history, nor was it Bakunin's prelapsarian collective, it was instead Camus's slave, declaring his humanity in the face of an unjust master and dying for the audacity.

29 Ibid., 149. 


\section{Bibliography}

Bakunin, Mikhail Aleksandrovich. God and the State. Mother Earth Pub. Assoc.

Beevor, Anthony The Spanish Civil War. Peter Bedrick Books. 1983.

Brenan, Gerald. The Spanish Labyrinth an Account of the Social and Political Background of the Civil War. Univ. Pr., 1967.

Camus, Albert. The Myth of Sisyphus. Penguin, 2005.

Camus, Albert. The Rebel. Penguin Books, 2013.

Casanova, Julian. Anarchism, the Republic and Civil War in Spain: 1931-1939. Taylor \& Francis, 2014.

Gerassi, John. The Premature Antifascists: North American Volunteer in the Spanish Civil War 1936-39; an Oral History. Praeger, 1986.

Guttmann, Allen. The Wound in the Heart: America and the Spanish Civil War. The Free Press of Glencoe, 1962.

Hochschild, Adam. Spain in Our Hearts: Americans in the Spanish Civil War 1936 - 1939. Mariner Books, 2017. 
Jackson, Gabriel. A Concise History of the Spanish Civil War. Thames and Hudson, 1974.

Kowalsky, Daniel. Stalin and the Spanish Civil War. Columbia University Press, 2008.

Proctor, Raymond L. Hitler's Luftwaffe in the Spanish Civil War. Greenwood Press, 1983.

Puzzo, Dante Anthony. The Spanish Civil War. Van Nostrand Reinhold Co., 1969. 
Hunter White 


\section{AUTHOR BIOGRAPHY PAIGE ROONEY}

Paige Rooney is a fourth year History major, minoring in Music and Anthropology/Geography. Her research interests include European colonization and imperialism, Latin American history, music and society, and the American West. Paige wishes to pursue a Master's degree in either Museum Studies or Public History in the near future. In her free time, she loves to play saxophone and piano, line dance, watch Marvel movies, and hike. 


\section{A $21^{\text {st }}$ Century Empire: The British Museum and its Imperial Legacies}

\section{PAIGE ROONEY}

Museums have a long history rooted in colonialism, but none come close to the lasting colonial legacy of the British Museum. Over the last several decades, governments and museums of former colonial powers have made efforts to repatriate cultural items which were taken from their colonies. Many museums around the world have all repatriated items and eliminated imperial images from their exhibits, but the British Museum has refused to do the same. ${ }^{1}$ Although the British Empire is long gone, cultural imperialism is still alive and well in many institutions, and the British Museum is the perfect example of this. By looking at various case studies of stolen artifacts and describing the recent repatriation controversies and issues, it is clear that the British Museum is still an imperialist

$1 \quad$ Emily Duthie, "The British Museum: An Imperial Museum in a Post-Imperial World,” Public History Review 18 (2011): 17. 
institution that uses their vast collections from the former colonies to maintain their power and continue the legacy of the British Empire.

Founded in 1753, the British Museum became one of the first national and public museums in the world. ${ }^{2}$ The museum would not have started without the donation of collections from Hans Sloane, an Irish physician and avid collector. Sloane began collecting in 1687 when he voyaged to Jamaica to serve as a physician to the governor of the colony. He returned to Britain with 800 plant and animal specimens, which would become the foundation of his encyclopedias on natural history. Upon his return, he built up his collection by absorbing the collections of his colleagues as well as buying items from travelers and explorers throughout the British Empire. As a result, his collection outgrew his two homes, and eventually he obtained 32,000 coins and medals, 50,000 books and manuscripts, 334 volumes of dried plants, and thousands more assorted items. ${ }^{3}$ Sloane died in 1753 at the age of 93, writing in his will that his collection would be left with King George II in exchange for 20,000 pounds for his son and on the condition that the government would create a museum to house his collection. ${ }^{4}$ Thus, Sloane's collection of assorted colonial items became the foundation of what would become the British Museum and was the beginning of an imperialist legacy.

Besides Hans Sloane's collection, some of the first items in

2 Duthie, "The British Museum," 12.

3 "Sir Hans Sloane," The British Museum - General History.

4 Hans Sloane, The Will of Sir Hans Sloane, Bart. Deceased. (London, 1753). 
the British Museum were classical antiquities, such as Greek vases, as well as Egyptian mummies and a random assortment of North American items. By the early $19^{\text {th }}$ century, the interest in classical antiquities grew immensely, and eventually the Department of Antiquities was split into three separate departments: Greek and Roman Antiquities, Coins and Medals, and Oriental Antiquities, which still remain today. ${ }^{5}$ The British Museum was so absorbed with ancient artifacts and collections from the British colonies that it was not until 1851, nearly a century after the founding of the museum, when the museum began to collect British and other European medieval objects. ${ }^{6}$ This demonstrates the perpetual colonial British obsession with the "other" and wanting to display fascinating objects from their colonies for their own country to see. Historian Emily Duthie states that "the British Museum could never be restricted to British things, for to do so would set a limit to the reach of British power, as well as to the gaze of the all-comprehending and autonomous subject." 7 This sense of power and superiority persisted throughout the colonial era in the British Empire and was exemplified especially in museums, where most items were taken from the colonies.

There are two major examples of looting during the colonial era: the Benin Bronzes and the Elgin Marbles. In 1897, the British led a punitive expedition in Benin, which is now in modern day Nigeria. Nearly one thousand bronze art pieces were seized by force from the royal palace of the Kingdom of Benin and two hundred of them went straight to the British Museum's collection. This type of

5 "History of the Collection," The British Museum - General History.

6 Duthie, “The British Museum," 14.

7 Duthie, “The British Museum," 15. 
expedition was typical of the British Empire, resulting in the plundering of art and the looting of cultural items. ${ }^{8}$ In addition, some Europeans believed these bronze plaques and figures to be so beautiful that they could not have been created by Africans, but instead claimed that these pieces of art were created by Portuguese sailors who had traveled through Benin.' Although Greece was not an official colony of the British Empire, the looting of the Elgin Marbles provides another perfect example of opportunism and imperialism. Thomas Bruce, the seventh earl of Elgin, traveled to Greece to bring back drawings and antiques to Britain. Instead, between 1801 and 1812, he forcefully removed numerous Parthenon sculptures and took them to London, where these items are now housed at the British Museum. ${ }^{10}$ Even after more than a century, both the Benin Bronzes and the Elgin Marbles still remain in the possession of the British Museum and are lasting imprints of aggressive imperialism.

In recent decades, the possession of such items as the Benin Bronzes and Elgin Marbles have become points of controversy. The governments of Nigeria and Greece have been demanding these items to be returned to them for decades, but they have been without luck. Nigeria has been longing for the return of the bronzes since its independence from Britain in 1960. However, the British Museum has resisted the permanent return of the bronzes due to legislation that bans museums from "permanently disposing of their

$8 \quad$ Ibid., 16.

$9 \quad$ Stephen Small, "Slavery, Colonialism and Museums Representations in Great Britain: Old and New Circuits of Migration," Human Architecture: Journal of the Sociology of Self-Knowledge 9, no. 4 (2011): 122.

10 Duthie, "The British Museum," 16. 
collections." ${ }^{11}$ Interestingly, the British Museum lent 35 of its 200 Benin Bronzes to the museum at the University of Pennsylvania in the 1960s. In fact, this was the first loan of any artifacts from the British Museum outside of England. ${ }^{12}$ The British Museum was willing and eager to loan these items to the United States, but was weary about repatriating, or even loaning, the bronzes to their country of origin. As of 2018, Nigeria has been open to accepting a loan of the artifacts rather than full repatriation as a compromise with the British Museum, and current efforts are being made, albeit slowly, to work out a loan agreement. ${ }^{13}$

On the other hand, Greece has been more demanding regarding the return of the marbles and will not accept a loan because they "should not have to borrow their own stolen property." ${ }^{14}$ One newspaper article from 1927 entitled "Greece Asks Return of the Elgin Marbles" describes the repatriation requests made by Greece, demonstrating the longtime prevalence of this issue. James Young, author of the article, believed that if the British Museum were to grant Greece's requests for restoration of the Elgin Marbles, the Parthenon would be restored to its original placement and more repatriations would occur in the future. ${ }^{15}$

11 Adam Lusher, "British Museums May Loan Nigeria Bronzes That Were Stolen from Nigeria by British Imperialists," The Independent, June 24, 2018.

12 John Canaday, "Art: African Bronzes in Philadelphia: British Museum Lends 35 Benin Plaques," New York Times (1923-Current File), July 14, 1965. 13 Josephine Livingstone, "The British Museum's Looting Problem," The New Republic, August 14, 2018.

14 Lusher, "British Museums May Loan Nigeria Bronzes."

15 James C. Young, "Greece Asks Return of the Elgin Marbles," New York Times (1923-Current File), July 3, 1927. 
However, little progress has been made to repatriate the marbles, and the issue still remains today. The Benin Bronzes and the Elgin Marbles are just two examples of how the British Museum has maintained their imperial power over "weaker" countries by refusing to return their highly prized cultural objects.

Following in Nigeria's and Greece's footsteps, other former colonies are now requesting repatriation of stolen artifacts, but the British Museum has refused on more than a few occasions. The issue of repatriation has been prevalent since the early $20^{\text {th }}$ century, but demands for repatriation of cultural items have increased exponentially since then, especially in more recent decades. There are many reasons why former colonies are requesting these items to be returned to them. In the case of the Elgin Marbles, the Greek government argues that the marbles are important pieces of heritage that represent the "Greek soul" and should be fully returned to their mother country. ${ }^{16}$ The British Museum may display such artifacts for their beauty and uniqueness, but "the colonized have been deprived of objects that are central to their historical narratives of identity." ${ }^{17}$ In addition, new museums are being created in these countries, such as the Acropolis Museum in Greece, that are prepared to house their own cultural objects with modern technology to protect their exhibits. Repatriation is also important to building up the self-esteem and sense of nationalism of the country of origin. ${ }^{18}$ Repatriation efforts give former colonies a voice on the world stage and empower them to stand

16 Celestine Bohlen, "Major Museums Affirm Right to Keep Long-Held Antiquities," New York Times (1923-Current File), December 11, 2002.

17 Duthie, “The British Museum," 22.

18 Ibid., 22. 
up to their former colonizer and demand the return of their own cultural objects.

Despite efforts by governments of former colonies, the British Museum has refused or ignored the majority of these requests for repatriation and believe that the museum's collections should remain intact. There is a major paradox concerning this institution's collections: the museum no longer accepts objects to its collections unless they were legally acquired, yet the museum also insists that the objects taken and looted during the era of the British Empire are "now part of the museum and, more broadly, the cultural heritage of the nation." ${ }^{19}$ Neil McGregor, director of the British Museum from 2002 to 2015 , claims that the institution is a "universal museum" and that it has evolved from being an "imperial war chest" to a "global resource," therefore still indirectly laying claim to the objects acquired under the British Empire. ${ }^{20}$ Because the British Museum sees itself as a resource of knowledge, it argues that cultural objects should remain in London because it is a widely visited city and will be seen by a large number of people from around the world. In addition, many believe that if the British Museum were to repatriate many of its objects, their museum would be nearly emptied. This belief perpetuates the assumption that the source nations of the antiquities are "unable to house and maintain their own objects and that they need London to preserve their history and heritage," ${ }^{21}$ which is a common imperialist view that has not changed. A newspaper article entitled "Concerning the Ethics of Loot" from 1904 states:

19 Duthie, "The British Museum," 18.

20 Ibid., 15.

21 Ibid., 21. 
For the possession of these marbles by the British Museum has proved the most efficacious means of preservation of some of the grandest masterpieces of the plastic art of ancient Athens, the sculptures which were left in their place at the Parthenon at the time of the conveyance to England having been subjected since then to the most lamentable injuries and deterioration through lack of proper care and wanton destructiveness. ${ }^{22}$

Even today, there are still advocates who claim that the British Museum is the rightful home of cultural artifacts belonging to other nations because they believe that they are the only ones capable of taking care of the items. In short, the British Museum's claims to ancient artifacts and its reluctance and refusal for repatriation further reinforce its past imperial policies and characteristics. ${ }^{23}$

Although museums are incredible spaces that provide an effective way of learning, beauty, inspiration, and knowledge, there are many ways in which museums can improve, specifically ethnographic museums, in order to "redefine their priorities in response to an ever more globalizing and multicultural world." ${ }^{24} \quad$ Campaigns by indigenous groups and activists have brought up arguments regarding repatriation, which have led to some successful repatriations and new museum policies in museums around the world. It is imperative for modern museum curators to know the imperial history of exhibits and to understand that context is extremely important

22 "Concerning the Ethics of Loot," Los Angeles Times (1886-1922), December $17,1904$.

23 Duthie, “The British Museum," 18.

24 Clare Harris and Michael O'Hanlon, "The Future of the Ethnographic Museum," Anthropology Today 29, no. 1 (2013): 10. 
in reflecting the meaning of an object. One example of this was Sir Richard Temple's collection, in which he described bows, arrows, and spears used for pig hunting and fishing as weapons and the "arms of savages," reflecting the British imperial project: the civilizing mission. ${ }^{25}$ The way in which an object or exhibit is displayed has the capability to alter the audience's interpretation of that object or exhibit. In addition, it is important to be transparent about the colonial history of certain items and how they were obtained. In a postcolonial context, it is considered inappropriate and culturally insensitive for museum curators to treat the material objects of other cultures as "exotica." Although this aspect has been continuously improving in recent years, the British Museum is far behind other institutions in this regard. For example, in 2017 the official Twitter account of the British Museum had an "Ask a Curator" session in which the public could ask them any questions about the museum and its exhibits. One question concerned the labeling of exhibits and making information available, to which the museum replied: "We aim to be understandable by 16-year-olds. Sometimes Asian names can be confusing - so we have to be careful about using too many." 26 The British Museum should aspire to a higher standard, especially considering the fact that the museum is built on its former colonies' items with "confusing names."

25 Claire Wintle, "Career Development: Domestic Display as Imperial, Anthropological, and Social Trophy," Victorian Studies 50, no. 2 (2008): 281. 26 Shazia Awan, "The British Museum Gleams with Stolen Riches from its Colonial Past - But Asian Names are Too 'Confusing' for Inclusion,” The Independent, September 14, 2017. 
The transition from being part of a powerful empire to a post-imperial institution has been challenging for the British Museum. By holding onto antiquities and cultural items from Britain's former colonies and claiming to be "universal museum," the British $\mathrm{Mu}$ seum has further perpetuated the issue of imperialism in the museum setting. Despite repatriation requests made by various countries, most notably Nigeria and Greece, there has not been much progress made by the British Museum to fully return the Benin Bronzes and the Elgin Marbles. Unless there are repatriations of cultural items to former colonies, compromises between governments, and improvements within the museum itself, the British Museum will continue to remain an imperial institution in a post-imperial world. 


\section{Bibliography}

Awan, Shazia. "The British Museum Gleams with Stolen Riches from its Colonial Past - But Asian Names are Too 'Confusing' for Inclusion.” The Independent. September 14, 2017. Accessed February 27, 2019.

Bohlen, Celestine. "Major Museums Affirm Right to Keep Long-Held Antiquities." New York Times (1923-Current File), December 11, 2002.

Canaday, John. "Art: African Bronzes in Philadelphia: British Museum Lends 35 Benin Plaques." New York Times (1923-Current File), July 14, 1965.

"Concerning the Ethics of Loot." Los Angeles Times (18861922), (Los Angeles, CA), December 17, 1904.

Duthie, Emily. "The British Museum: An Imperial Museum in a Post-Imperial World.” Public History Review 18 (2011): 12-25.

Harris, Clare, and Michael O'Hanlon. "The Future of the Enthnographic Museum.” Anthropology Today 29, no. 1 (2013): 8-12. 
"History of the Collection." The British Museum - General History. Accessed March 1, 2019.

Livingstone, Josephine. “The British Museum's Looting Problem." The New Republic. August 14, 2018. Accessed February $27,2019$.

Lusher, Adam. "British Museums May Loan Nigeria Bronzes That Were Stolen from Nigeria by British Imperialists." The Independent. June 24, 2018. Accessed February 27, 2019.

“Photographic Print, Af,A60.25.” British Museum Collection Online, 1897-1898.

"Sir Hans Sloane." The British Museum - General History. Accessed March 1, 2019.

Sloane, Hans. The Will of Sir Hans Sloane, Bart. Deceased. London: Printed for John Virtuoso, 1753.

Small, Stephen. "Slavery, Colonialism and Museums Representations in Great Britain: Old and New Circuits of Migration." Human Architecture: Journal of the Sociology of Self-Knowledge 9, no. 4 (2011): 117-27.

Wintle, Claire. "Career Development: Domestic Display as Imperial, Anthropological, and Social Trophy." Victorian 
Studies 50, no. 2 (2008): 279-88.

Young, James C. "Greece Asks Return of the Elgin Marbles." New York Times (1923-Current File) (New York, N.Y.), July 3, 1927. 


\section{AUTHOR BIOGRAPHY KALI DEVARENNES}

Kali deVarennes is a second-year History major with a Law and Society minor from Agoura Hills, California. She worked at a law firm in Los Angeles last summer and is returning as a legal assistant this summer. In her free time, she enjoys being involved with her sorority, hanging with friends, and going on hikes with her dog. After graduating in 2021, she plans on going to law school. 


\section{North Vietnamese Women in War: Redefining Victory and Gender Roles}

\section{KALI DEVARENNES}

Laurel Thatcher Ulrich said it best, "Well behaved women seldom make history." ${ }^{1}$ The role of women in many societies has often been overlooked. Typically, women were expected to be housewives, and to be emotional and submissive to men. Women across the world have challenged gender norms and defied gender discrimination. During the Vietnam War, North Vietnamese women played prominent roles, although their contributions often went unrecognized. The evidence and accounts within this paper demonstrate their contributions, as well as their strength and fortitude. Not only did they serve as doctors and nurses, but they fought as fierce warriors who endured the hardships of war equivalent to their male counterparts. $1 \quad$ Lavoie, Amy. "Ulrich Explains that Well Behaved Women Should Make History." The Harvard Gazette, September 20, 2007, https://news.harvard.edu/gazette/ story/2007/09/ulrich-explains-that-well-behaved-women-should-make- history/. 
This essay explores the various responsibilities of North Vietnamese females in the war and discusses their experiences. Despite previous assumptions and standards about the expectations of North Vietnamese women, their actions in the Vietnam War highlight the transformation of traditional gender roles.

While the participation of North Vietnamese women in war is known in Vietnam, it is unevenly recognized and constitutes a sort of hidden history in American understandings of the war. The harshness of the Vietnam War was a painful reality for the United States and, perhaps unsurprisingly, recognizing North Vietnamese women for their war efforts was not at the forefront for Americans. Because of these circumstances, there is a major problem accessing resources that documented these experiences. However, the sources within this paper provide details that reveal the inspiring contributions North Vietnamese women made to the war. From the Vietnamese Trung sisters fighting against China in 40 A.D. to the warriors who served in the Vietnam War, these women played an integral part in redefining gender roles. ${ }^{2}$ This essay will also include the perspective of then twenty-five year old North Vietnamese physician, Dr. Dang Thuy Tram. However, the other sources within this paper will focus on the women who had military roles, which is the occupation that is most overlooked, yet most intriguing.

With this in mind, it is beneficial to understand what led to the involvement of North Vietnamese females in the Vietnam War. teractions of Women Strike for Peace, the Vietnamese Women's Union, and the Women's Union of Liberation, 1965-1968," Peace \& Change 37, no. 3: 354, doi:10.1111/j.14680130.2012.00754.x. 
After the end of French colonial rule in Vietnam, several countries attended the 1954 Geneva Conference to reach an agreement to split Vietnam at the 17th parallel into a North and South and to hold nationwide free elections. ${ }^{3}$ The democratic elections failed to take place due to the U.S. fear of Ho Chi Minh and the Communist Party winning the election. ${ }^{4}$ Hence, the United States took the matter into its own hands. The U.S. initially had a background role in the war and let the North and South do most of the fighting on their own, but they supported the success of the South. ${ }^{5}$ However, in 1964 the Gulf of Tonkin incident occurred, which dragged the U.S. into total war against North Vietnam. ${ }^{6}$ There were several misconceptions between the North Vietnamese and the U.S. regarding this incident. Nevertheless, U.S. attacks against the North rapidly ensued.. ${ }^{7}$ By 1965 , the U.S. and the North were engaged in a brutal, bloody war.

As a result, Ho Chi Minh saw the need for women and the

3 Pierre, Asselin, "The Democratic Republic of Vietnam and the 1954 Geneva Conference: a Revisionist Critique," Cold War History 11, no. 2 (May 2011): 155, https://doi:10.1080/14682740903244934.

4 Jessica M., Frazier, "Collaborative Efforts to End the War in Viet Nam: The Interactions of Women Strike for Peace, the Vietnamese Women's Union, and the Women's Union of Liberation, 1965-1968," Peace \& Change 37, no. 3: 340, doi:10.1111/j.1468-0130.2012.00754.x.

5 Marolda, Edward J. "Grand Delusion: U.S. Strategy and the Tonkin Gulf Incident.” Naval History 28, no.3 (August 2014): 25, http://search.ebscohost.com.ezproxy.lib.calpoly.edu/login.aspx?direct=true \&db=aph\&N=969219 $95 \&$ site $=$ ehost-live.

6 Ibid.

7 Marolda, Edward J. "Grand Delusion: U.S. Strategy and the Tonkin Gulf Incident.” Naval History 28, no.3 (August 2014): 26, http://search.ebscohost.com.ezproxy.lib.calpoly.edu/login.aspx?direct=true $\& d b=a p h \& N=969219$ $95 \&$ site $=$ ehost-live. 
important role they could play in the war effort. He demanded that Vietnamese women participate in the war and that they uphold three responsibilities: "continue production when men went into the army so that the people would be fed, to run family affairs and care for their children, and to fight the enemy when necessary." ${ }^{8}$ Minh knew that the involvement of females in the war would serve as inspiring propaganda to the public when his male soldiers became deflated.' However, the new roles provided by Minh prompted women to embrace the ideal of serving their country and prove that they could perform with the same standards expected of men. They in turn expressed themselves in a fierce and tireless manner by transforming into combative soldiers.

During the Vietnam war, these North Vietnamese women who actively participated in battle were known as the long-haired warriors. They asserted that "when war comes, even women have to fight," which was a phrase they carried with them throughout the war. ${ }^{10}$ For decades, these women would never have considered playing active combat roles. In the past, Vietnamese women were beat for not being submissive and were forced to stay at home. ${ }^{11}$ However, the long-haired warriors redefined these standards in the war. They endured horrific methods of torture including sticks being shoved

$8 \quad$ Sandra C. Taylor, “The Long-Haired Warriors," In the War that Never Ends, ed. David L. Anderson and John Ernst (Lexington: The University Press of Kentucky, 2014.), 172.

$9 \quad$ Ibid.

10 Sandra C. Taylor, “The Long-Haired Warriors," In the War that Never Ends, ed. David L. Anderson and John Ernst (Lexington: The University Press of Kentucky, 2014.), 167.

11 Ibid, 169. 
underneath their fingernails and electric shock to their sexual organs. ${ }^{12}$ What these women had to endure challenged the traditional view of Vietnamese womanhood. ${ }^{13}$ They were no longer subjected to the constraints of domesticated life and embraced their new roles as fighters. The long-haired warriors tackled responsibilities that were unheard of for women, especially at that time. A few of their jobs included "camouflaging antiaircraft guns, [and] supplying clothing, food, and drink to the battlefield." They were also prepared to defend villagers from the Americans. ${ }^{14}$ Through these actions alone they redefined what it meant to be a strong, empowering woman. They overcame torture and discrimination while proving their ability to fight, actions which demonstrated the drastic shift in gender roles.

On the other hand, while North Vietnamese women had a strong presence in the military, some Vietnamese men did not support this. Even though Ho Chi Minh stressed the importance of these females in war, many of the male soldiers believed that they should remain at home and continue to have domestic roles such as cleaning, farming, and taking care of children. ${ }^{15}$ This perception of North Vietnamese women did not prevent Minh from utilizing them to his advantage.

12 Sandra C. Taylor, “The Long-Haired Warriors," In the War that Never Ends, ed. David L. Anderson and John Ernst (Lexington: The University Press of Kentucky, 2014.), 172 .

13 Jessica M., Frazier, "Collaborative Efforts to End the War in Viet Nam: The Interactions of Women Strike for Peace, the Vietnamese Women's Union, and the Women's Union of Liberation, 1965-1968," Peace \& Change 37, no. 3: 342, doi:10.1111/j.14680130.2012.00754.x.

14 Sandra C. Taylor, “The Long-Haired Warriors," In the War that Never Ends, ed. David L. Anderson and John Ernst (Lexington: The University Press of Kentucky, 2014.), 179.

$15 \quad$ Ibid, 174. 
The women who fought for the National Liberation Front wore all black and were expertly trained to use a variety of weapons. ${ }^{16}$ Using these weapons was new to North Vietnamese females, but it broke the barrier of men being the only combatants capable of operating weaponry. Many of these women were young, usually in their teens or early twenties, but could still carry heavy items, shoot large guns and mortars, and make bombs (Fig.1). Photographs of women much like the one depicted in Fig. 1 circulated the globe and encouraged others to join the revolution. ${ }^{17}$ Vietnamese women within the National Liberation Front used this as an opportunity to promote ideas of freedom from their traditional roles.

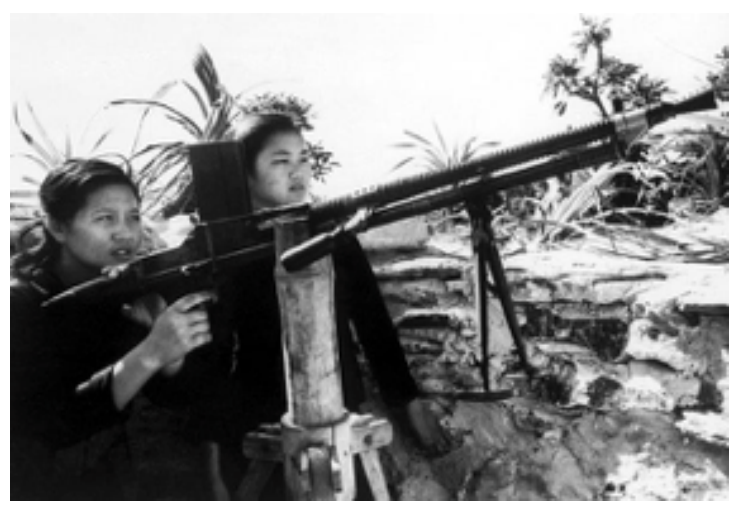

Fig.1: North Vietnamese Women Learning to Use a Machine Gun. Digital Image. New York Times. June 6, 2017. https://www.nytimes. com/2017/06/06/opinion/vietnam-war-women-soldiers.html.

16 Sandra C. Taylor, “The Long-Haired Warriors," In the War that Never Ends, ed. David L. Anderson and John Ernst (Lexington: The University Press of Kentucky, 2014.), 179.

17 Sandra C. Taylor, "The Long-Haired Warriors," In the War that Never Ends, ed. David L. Anderson and John Ernst (Lexington: The University Press of Kentucky, 2014.), 173. 
In addition to the commitment of these fearless women serving in the war as soldiers, other women aided the North off the battlefields. Dr. Tram's memoir Last Night I Dreamed of Peace emphasized the role of North Vietnamese women in the medical field. This memoir reflected Tram's experiences in 1968 when she worked as a female doctor along the Ho Chi Minh Trail in South Vietnam, which was constructed largely by North Vietnamese women. ${ }^{18}$ Tram left her hometown of Hanoi to aid wounded soldiers. She witnessed soldiers with severed spines, amputated limbs, punctured organs, and many more horrific injuries. Perhaps the most tragic and gruesome encounter she had was on July 29, 1969, when an American-planted phosphorus bomb burned a Vietnamese soldier to the point where his skin slowly fell to the floor in crisp chunks, and his eyes were black holes. ${ }^{19}$ She also treated one of her fellow nurses, who was hit by shrapnel while working. The mortar paralyzed him as the nerves in his spine were destroyed immediately. ${ }^{20}$ Seeing her patients' conditions fueled her hatred of war and of the Americans, but she continued to overcome the adversities. ${ }^{21}$ While her accounts in her memoir show a very different role from the long-haired warriors, her actions were equally as important to the revolution. As a doctor, she expressed her support for the National Liberation Front and knew that it was her duty to save as many individuals as she could. She experienced some of the worst parts of the war, which revealed that

18 Ibid, 171.

19 Dang Thuy Tram, Last Night I Dreamed of Peace (New York: Three Rivers Press, 2007), 142.

$20 \quad$ Ibid, 38.

21 Ibid, 39. 
women were no longer shielded from realities of war long associated with men.

Similarly, Le Thi Dau, a nurse for the National Liberation Front, joined the revolution at only fifteen years of age and witnessed many women in the war who suffered from chronic depression. ${ }^{22}$ Although Dau also experienced a very tense environment similar to Tram, she also claimed that serving as a nurse was often exciting and gave her rushes of adrenaline. ${ }^{23}$ These women embraced their roles and felt liberated from their domesticated lives. Whereas they were brought up to be submissive and take care of the home, their participation in battle allowed them to express themselves in ways they had never experienced. Although Dau and Tram were under a lot of pressure, they were able to overcome countless obstacles and persevered through the worst conditions. The encounters they faced are hard to process, but it allows for reflection and appreciation for these North Vietnamese women, regardless of their roles in the revolution. Because Tram worked in several places throughout the war, since her clinics were repeatedly destroyed by American forces, she was often in the heart of battle alongside other Vietnamese female fighters. In one of her diary entries, she revealed how late at night she saw American "jet planes drop bombs all over the hamlet...and [fire] streams of bullets down onto the battlefield." ${ }^{24}$ Vietnamese women in the war had to be prepared for anything no matter what their role was.

22 Michael Hunt, A Vietnam War Reader: A Documentary History from American and Vietnamese Perspectives (University of North Carolina Press, 2010), 176.

23 Ibid.

24 Dang Thuy Tram, Last Night I Dreamed of Peace (New York: Three Rivers Press, 2007), 122. 
Whether it was Tram and other nurses treating patients or the longhaired warriors operating gunners, they knew they had to endure the stresses of war and prove they could handle the same responsibilities given to men.

On June 22, 1970, U.S. soldiers heard faint noises of a radio and spotted Tram walking and killed her instantly; however, soldiers discovered her diary amidst the other documents at the camp. ${ }^{25}$ In April 2005, when the military was sifting through military records to burn, Sergeant Nguyen Trung Hieu stopped his comrade Fred from throwing Tram's diary into the fire, as he claimed that Tram's diary "[had] fire in it already." 26 This excerpt alone represents Tram's values and her dedication to the war. Her diary was eventually published and allowed individuals to see what kind of roles North Vietnamese women had in the war. While her recollection of events was geared towards the encroachment of America on Vietnam, her detailed experiences revealed how North Vietnamese women were crucial to the war effort despite previous assumptions about their capabilities.

Additionally, many North Vietnamese women were so dedicated to the war that they often started as nurses and transferred to the military after. For example, Mrs. Hoang Thi Khanh, the Vice President of Vietnam's General Confederation of Labor, started as a nurse in the Vietnam War and eventually became part of the special forces as an undercover agent. ${ }^{27}$

$25 \quad$ Ibid, 225.

26 Dang Thuy Tram, Last Night I Dreamed of Peace (New York: Three Rivers Press, 2007), 225.

27 Sandra C. Taylor, "The Long-Haired Warriors," In the War that Never Ends, ed. David L. Anderson and John Ernst (Lexington: The University Press of Kentucky, 2014), 
After the National Liberation Front underwent heavy losses in the Tet Offensive, Khanh helped recruit women to form a guerilla force that would contribute to the revolution. ${ }^{28}$ She wanted women present because she knew they had the capability to serve and protect their country. Many of them were eager to leave their home and fight for a cause, while others wanted peace and reunification with their families. ${ }^{29}$ Khan's job as a nurse did not end her involvement in the war as she continued to fight for her country. She proved that North Vietnamese women could expand on their role in society and redefine traditional roles that were thoroughly ingrained.

Overall, the roles of North Vietnamese women in the Vietnam War have not been given as much attention as deserved. This paper provides a new perspective on not only these women but on how gender roles immensely transformed during this period. Notably, there was a lack of focus on North Vietnamese women in war, but Ho Chi Minh was confident in his implementation of women in the revolution. The fact that Minh believed in North Vietnamese women to take on several new, unfamiliar roles should be enough to understand their importance. Women during this period were warriors and educated doctors and nurses that overcame adversity. Understanding their history is an important tool to use when gaining perspective on gender roles. Women and feminist groups today can use the history of North Vietnamese women as a platform for defying traditional gender roles and the treatment of women. Including 176.

28 Ibid.

29 Michael Hunt, A Vietnam War Reader: A Documentary History from American and Vietnamese Perspectives (University of North Carolina Press, 2010), 175. 
the experiences of Vietnamese women will allow others to consider other perspectives and divert from stereotypical roles. Understanding other countries and cultures and how their actions affected societal change promotes diversity and inclusion. Ultimately, North Vietnamese women proved that gender roles would not define them during a period in history fraught with division. 


\section{Bibliography}

Asselin, Pierre. "The Democratic Republic of Vietnam and the 1954 Geneva Conference: A Revisionist Critique." Cold War History 11, no. 2 (May 2011): 155-95. https:// doi:10.1080/14682740903244934.

Dang, Thuy Tram. Last Night I Dreamed of Peace. New York: Three Rivers Press, 2007.

Frazier, Jessica M. "Collaborative Efforts to End the War in Viet Nam: The Interactions of Women Strike for Peace, the Vietnamese Women's Union, and the Women's Union of Liberation, 1965-1968." Peace \& Change 37, no. 3 (July 2012): 339-65. https://doi:10.1111/j.1468-0130.2012.00754.x.

Herman, Elizabeth. "The Women Who Fought for Hanoi." New York Times, June 6, 2017. https://www.nytimes. com/2017/06/06/opinion/vietnam-war-women-soldiers. html.

Hunt, Michael H. A Vietnam War Reader: A Documentary History from American and Vietnamese Perspectives. Chapel Hill: University of North Carolina Press, 2010. 
Lavoie, Amy. "Ulrich Explains that Well Behaved Women Should Make History." The Harvard Gazette, September 20, 2007. https://news.harvard.edu/gazette/story/2007/09/ulrich-explains-that-well-behaved-women-should-make-historyl.

Marolda, Edward J. "Grand Delusion: U.S. Strategy and the Tonkin Gulf Incident." Naval History 28, no.3 (August 2014): 24-31. http://search.ebscohost.com. ezproxy.lib.calpoly.edu/login.aspx?direct=true \&d$\mathrm{b}=$ aph\&N=96921995\&site=ehost-live.

Taylor, Sandra C. “The Long-Haired Warriors." In The War that Never Ends, edited by David L. Anderson and John Ernst, 168-189. Lexington: The University Press of Kentucky, 2014.

Taylor, Sandra C. Vietnamese Women at War: Fighting for Ho Chi Minh and the Revolution. Lawrence: University Press of Kansas, 1999. 


\section{EDITORS}

\section{KELLY BARR}

Kelly is a third year History major and returning editor to The Forum. His favorite areas of history are America in the twentieth century and England in the sixteenth century. He is from Alamo, California and enjoys surfing, rock climbing, and reading.

\section{JACOB LAFARGA}

Jacob Lafarga is a third year History major and Ethnic Studies minor. His main historical interests include the Civil War, Cold War Latin America, American Presidents, and the Supreme Court. When he isn't doing history related activities, you can find him taking scenic drives, playing video games, reading biographies, having passionate debates about movies, or enjoying an ice cold beer while watching the Lakers play.

\section{JOHN IMOBERSTEG}

John is a fourth year History and Political Science (Pre-Law) major from San Jose, California. His areas of interest are military history, American history, and the development of legal systems. Outside of The Forum he is active in the Cal Poly Rugby Club, a member of Phi Alpha Theta, and part of the undergraduate law association. A few non-academic hobbies include backpacking, fishing, and genealogy. After graduation from Cal Poly in Spring 2019 John will be attending law school at the University of San Francisco. 
